\title{
THE EFFECT OF BASE COURSE
}

GRADATION ON THE RESULTS OF LABORATORY PUMPINE TESTS

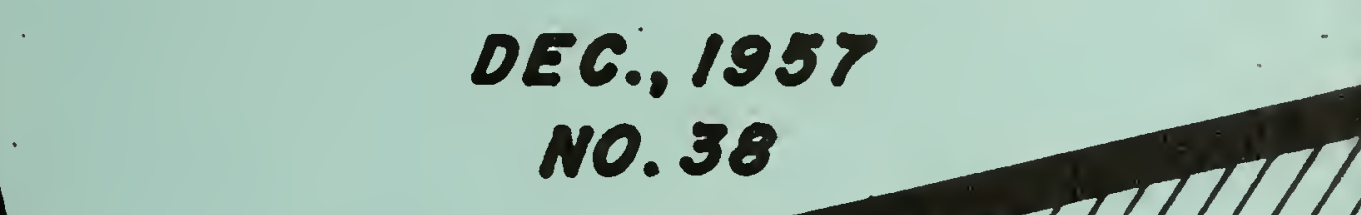


TECHNICAL PAPER

THE EFFECT OF BASE COURSE GRADATION

ON THE RESULTS OF LABORATORY PUMPING TESTS

TO: $\mathrm{X}, \mathrm{B}$, Woods, Director

Joint Highwey Research Project Decenber $1.8,1957$

FROM: H. Lo Hichael, Assistant Director Pjle: 6-18-6

Attached is a technical paper entitled, "The Effect of Base Course Gradation on the Results of Iaboratory Pumping Tests " by $W_{0} P_{0}$ Chambirlin, and $E_{0} J_{0}$ Yoder. The paper will bo presented at the 37th Annual Heoting of the Highway Research Board in January, 1958。

The paper 18 a sumary of research performed on a variety of base course samples with different gradations. The research was performed under a contract with the Artic Construction and Frost Effects Laboratory of the Corps of Englneers.

The paper 28 presented to the Board as information.

$$
\text { Respectfully subaittod }
$$

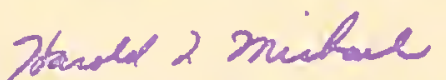

Harold L, Michael, Assistant Director

HLM: hgb Joint Highway Research Project

Attachment

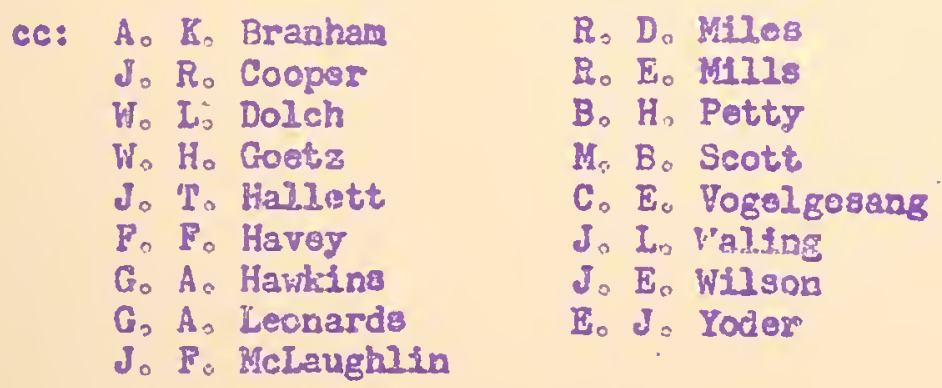


Digitized by the Internet Archive in 2011 with funding from

LYRASIS members and Sloan Foundation; Indiana Department of Transportation 
TECHNICAL PAPER

THE EFFECT OF BASE COURSE GRADATION

ON THE RESULTS OF IABORATORY PURPING TISTS

\author{
by \\ $W_{3} P_{3}$ Chamberlin \\ Formerly Graduate Assistant \\ and \\ E. J. Toder \\ Ressarch Engtneer
}

JoLnt Highway Resoarch Project

Plio: $6-18 \mathrm{~s}$

\author{
Purdue Univeraity \\ Lafayetto, Indiana
}

Decenber 18,1957 


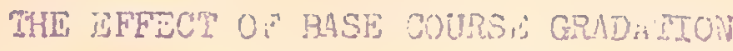

ON TIH: WUSULTS OF IABORATURY PU.MTH TUES

BI

W. Do Ghanterling USAF

E. J. Yoder, Purdue rrivesajty

STMOPSIS

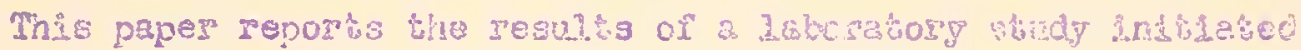

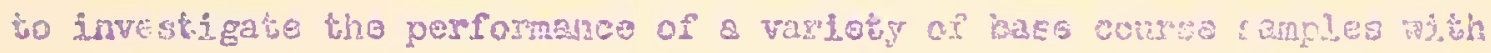
different gradations, when thissis samples apa placed ove: a siasdarot subw

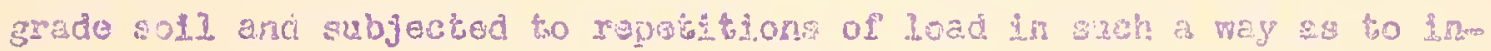

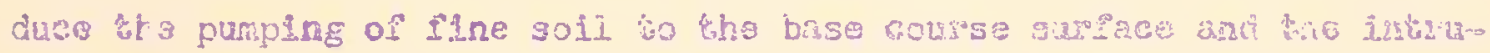

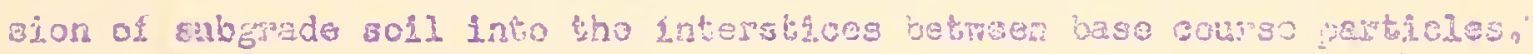
To accompjish the puxpose of this Lnvesfigationg elght grovel

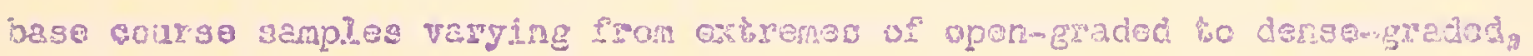

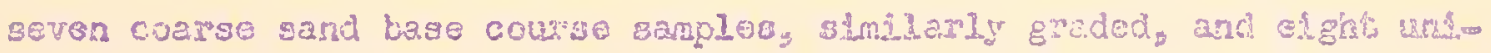

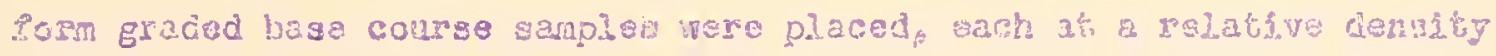

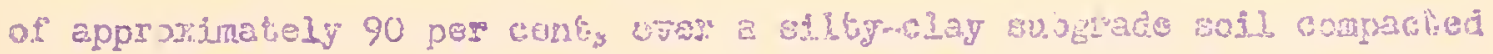

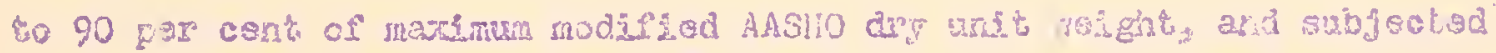

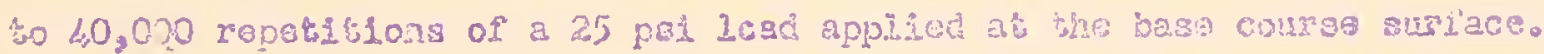

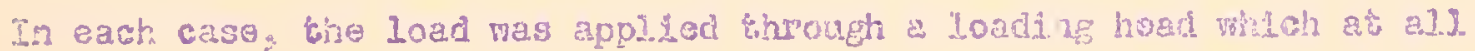

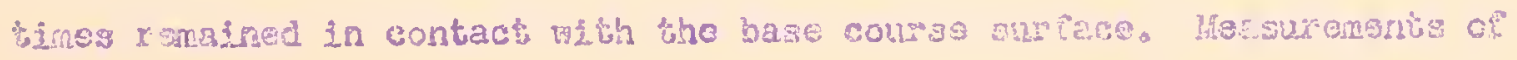

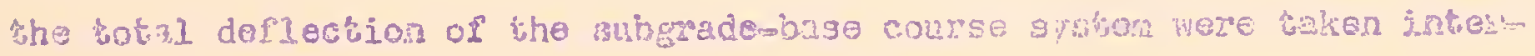

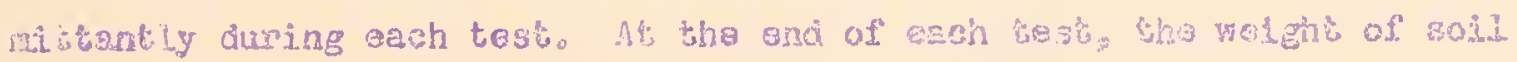

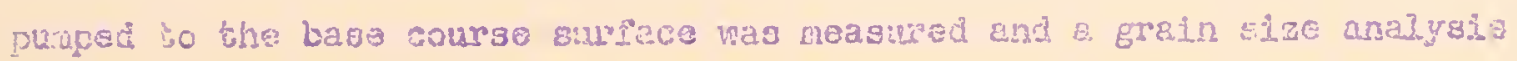

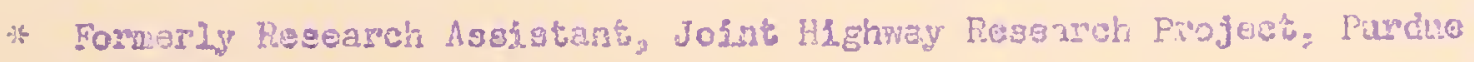
Univarsity 
$\therefore \quad x^{2} \cos$ and ins

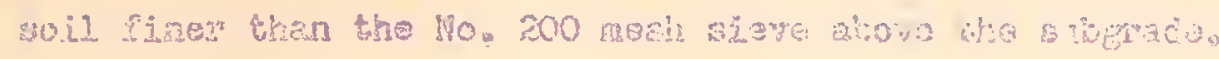

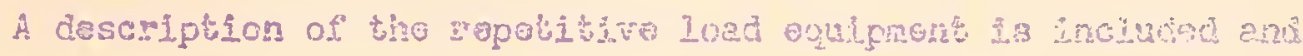

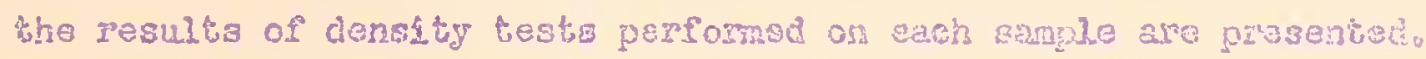

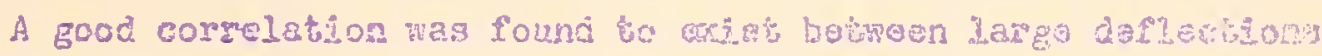

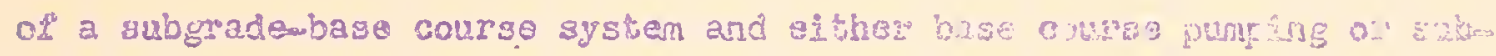

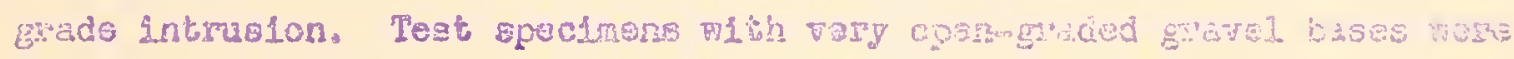

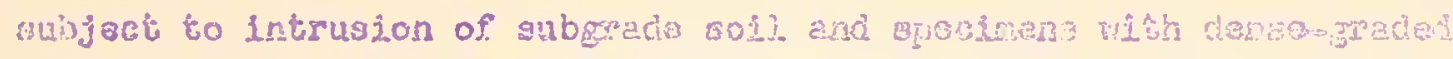

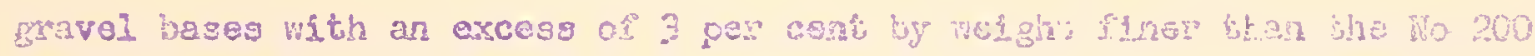

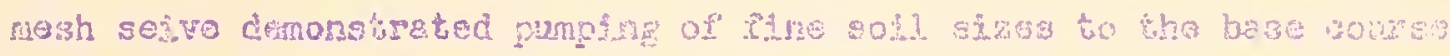

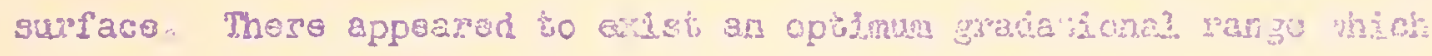

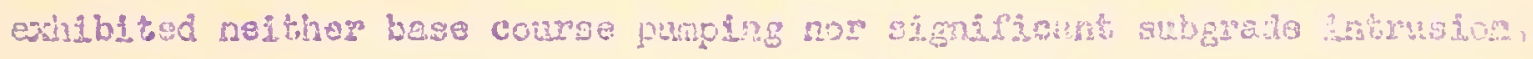

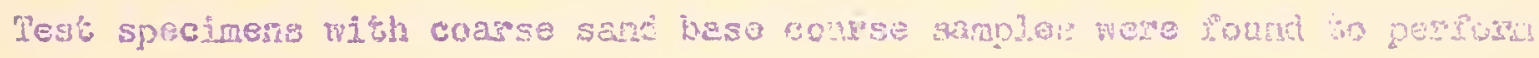

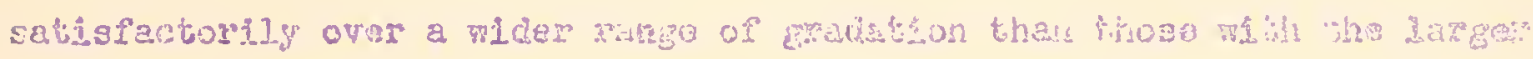

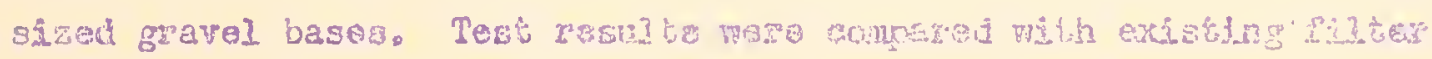
criturid ior this base coursta 


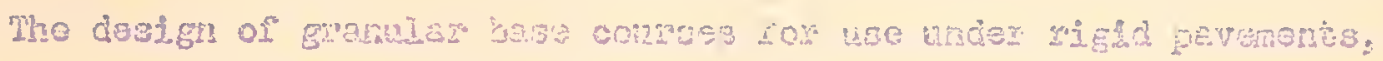

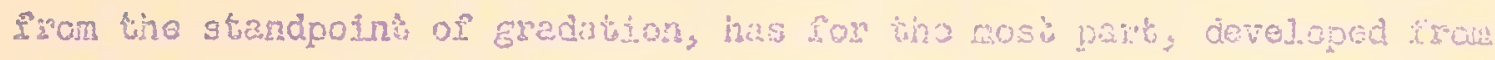

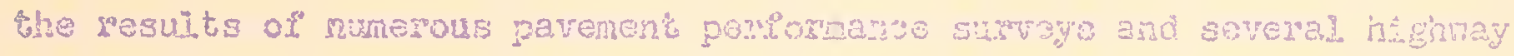
test sections $(1,18,19,29)$. These porformance gurvegs have becr conm ducted and these test scctions built by the hishny dopartents of the

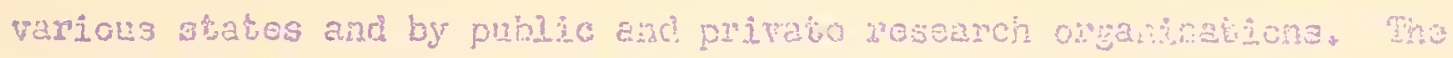

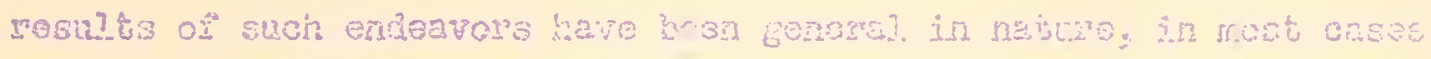

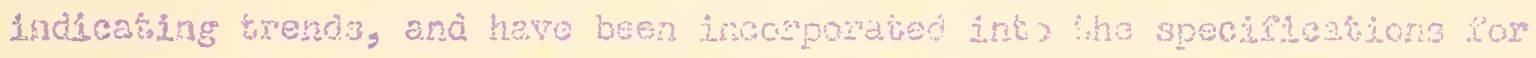

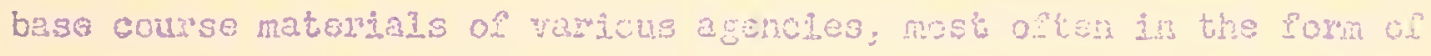

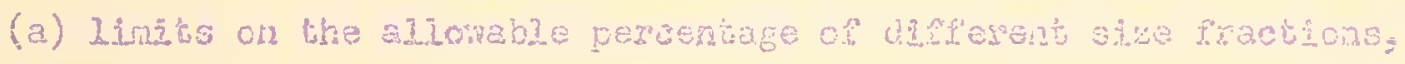

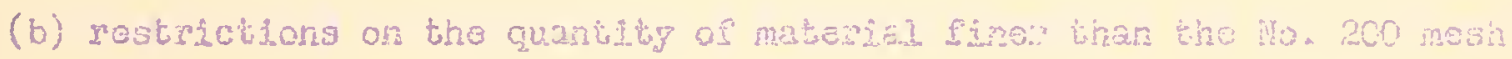

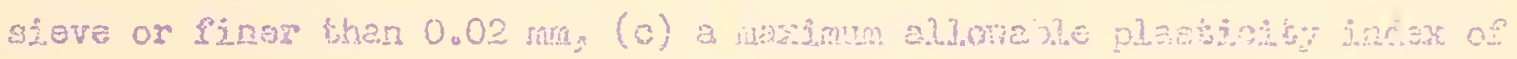

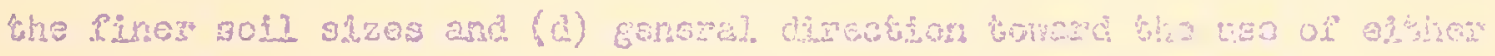

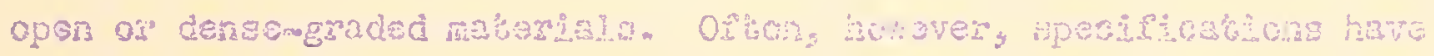

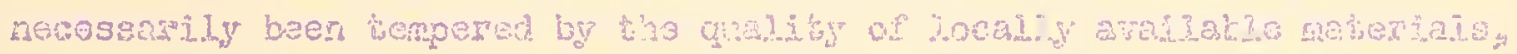

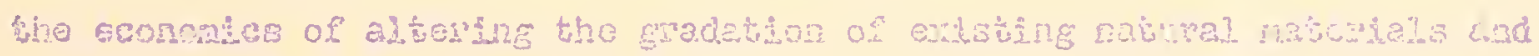

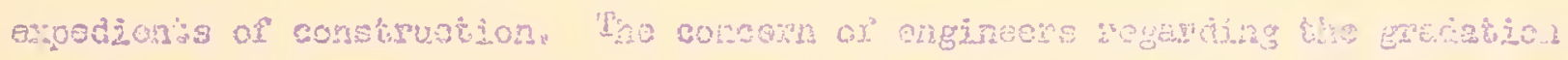

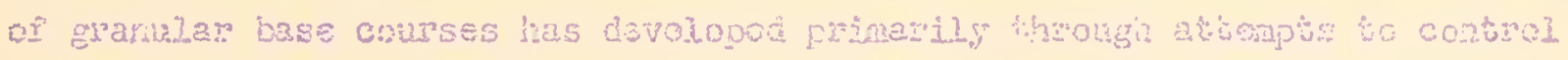

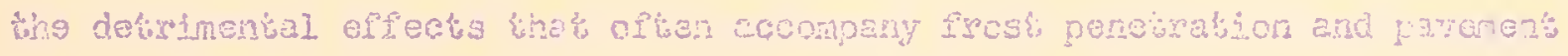

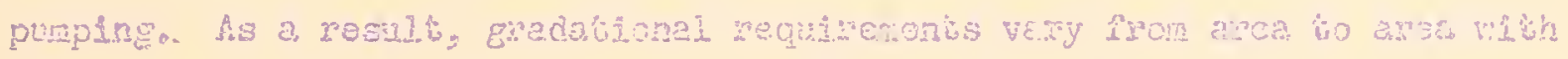

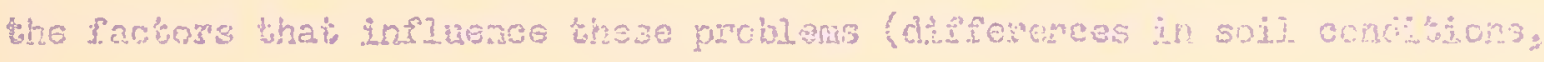

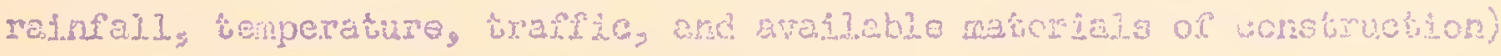

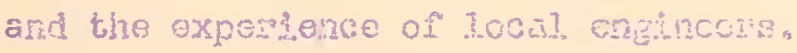

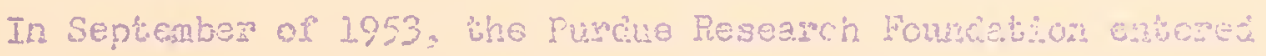

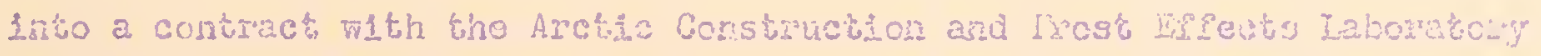
of the Corps of linginesrs, U. 3. Army to study bace course requizements 
for rigid paverents constructed over frostmsusenptible subyrudes. The purpose of this study was to provido data to etther substantiato or rovise existing critoria reialive to raquired thickness ario quality in areag which experience signiflcant frosis penetretiono

This intrestigation consisted of tho prases, an extensive fleld and office corrolative study of highway anc aixfleid pavaments (32) * and a statistical laboratory, study to evaluate tho relative influence of various subgrade and base course factors on the punping of rigid pavew ments $(17)$.

The fomer included a literature search of current alrfield and highway prectices, field observations :t se?ected as installations. and an edge sampling program and perfomance survoy of rifgld pavaments In Indiana constructed mith granular subgrado freatment. Dasa obtained from this study indicated thut periormance of angid highway pavements built with granular bases is greatly influenced by the gradation of the base courge material.

At the $\operatorname{san} \theta$ time tha laboratory siudy shoms that the performase of a subgrade-base course system cannot be explained solely by a consideration of the direct effects of ono selorted factor as base course gradation, but ratiner is dependent to some extents on tive interaction betwean a numbes of factors; such as, subgrade type and compaction, base course type and cons paction, and the magnitude of the applied load. It that if selection of a base course tgpe is feesibie in a given situation, one with an open tertured gradation should bo chosen gince it would be apt to deflect less under repeated loads than a dense-textured base until the total deflection of the lattar had Increased to a point whore structural fallure of the overlying pavement could be postulated.

* Numbers in parenthesis refer to iteras 21sted in the bibliography. 
In an investsgation of this natise, it is inportant that the event being observed be definad so that test aesuite may be viowod Fith the proper porspective. No attampt is made to goviow sho latarature pertaining to pavsnent pumping as this has been done many times by others. The following comments, however, present a concept of pumpling action which may or may not be in contraet to thas of othoss. It is inportiant to note that theso remarks apply only to punping of rigid pavenents built on granular basos. Punping of finomgrained solis has racelved attention by many investigators and mill not bo discussed hore.

1. Pumping action, why respect to rigid highway op airfideld pavenents constructed over granular base ecurses; is an inclusiro torn rolating to the movenent of finez soil sizes (sand, gilt, and clay), Which exist beneath a pavement surface. Removal of ifine soil gizes results frorn the rather rapid movement of $w$ ter carrying weth it soll particlas elther in suspension or in motion as a result of hydrodynarafe forces; the water moving under a pressure differontial caused directy or indirsctly by the deflection of a loaded pavement slab. This action may be minor and produce no significant pavement distress or it may resule In severo pavement damage. Th5s action may procoed rox varying pertode of time before surface evidencss of tit aro discornible. The action is generally intermittant or cyclic in naturo over a given period of time.

2. Pumping action may consist of one or a!l of the following: a. The moremont of purticles from and about the hase course surface This aspect of pumping is erosional. In nature and results from the latoral movement of free wator along the base course surface as a result of displacement by a deflecting slab causing water and soil, upon 
occasions, to be ejected at pavernent joints, cracks, and edges. The conditions nocessary for this type of pumping to cccur are: the existance of a void space betmesn the pavenent slad and the base course surfaces the presence of a small ancunt of free water on the bese course surface. and the existance of particles small enough to be moved. This type of pumping has been tarned "blowisg" by some invegtifidiors.

\section{b. The movement of the flne: soil stzes whing and out of} the base course This aspect of punping mya result fron the reloase of pore water pressures or by elutriation if deflecitons pithin the base course are great onough. Comdltions necessary for this tgpo of pumping to cccur are: a high degree of satumaton of the base caurse sitin the presonce of free water to it least ths base course surface, deflection In the base course sufficient to cause tho dorelopragt of adecuate pore water pressures, nore azes in the baso course of zuffictent size to permit the morenent of fino eoiz pareflcles, and soju pirtulcles within the base course small enough to be moved. This type of punping has beon Induced in laboratory tests (17)。

\section{c. The movement of subgrade soll into the incerstices}

betmeen base course particleg It has bean postulated (17) that this might rasult from the release of pore pitter pressure developed in a softened subgrade soil resulting from the transmision of load through a granular base course to the subgrads surface. A distinction is made hera betmeen this aspect of pumping and the intermixing of subgrade and base course that nay result fron a kneading action. Tho latter 13 not cons

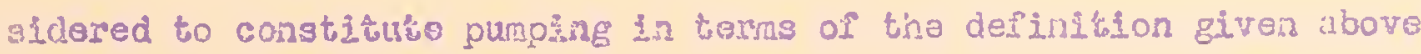
but, rather, is related to local shearing feilures of the subgrade soll at its surface of contact mith the hase courss. The conditions considered 
recessary for this typo of punping to o:cur are: a high claglee oj. Baturation of the subgado soli. so that approciablo poro wator prossuras will result from amall defjections of a zcaded pavarent, cohesive conta In the subgrado soll which are not strong anough to rasist the hoydrodynamie forees of escaplng pore vatsr, a compressivie subgiade soil, a base courge which is many times more permeable shen tho subgrate, a sourea of evaliable ground rater, and pores in the adjacent base covrsa naterial of suffichent size to pemit the entrance and fnovenent or gubgrate soli partisies. 
It was the purpose of this research progran to investigate by means of repeated load tests, the performance of a veriety of bass courso gradations vith respect to the movement of fine so:l to the base course surface and the movenont of subgrado soll into the interst1cas betrin buse courso paricles. To accomplish this investigation, eight gravel bass courso samples varying from extremes of open-graded to densomgraded, seven coaris 3and baso course samples sindlarly graded, and a sories of unjormmgrader! aamles werg placed, each at a relative density of approsinately 90 psr sent, over a standard sil.tg=hay subgrade compacted to 90 per cent of modifled ASHO density, and subjectod to repetitions of a 2\%, psi load applied at the base courso surface. In each case, the load we:s applied through a loading piston which at 211 blnes remained 25 contect thith the baso course surfaco. It was posstble mith this type of test fic incice the movement cir fins through and out of the base course as vell as the intruslon of gubm grade soll into the intorstices botween baso cous'se particles by a pumplng action oy by mecherical manipulation or kneading at the subgradombaso course surface of contact. It was recognizod that there are other aspects of base ecurse perfornance; for instanco, pexmeabulisy, which aro dependent upon gradet1on: biü these wore not constered. 


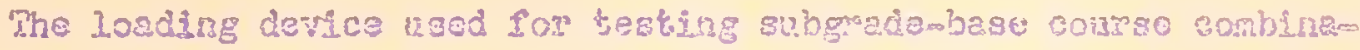
tions 18 shown in Figures 1 and 2. Eseanidaly this piece of equipnent

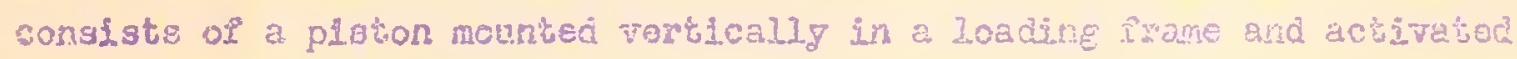
by compressed ajs. Tho pressure appled at the pidton face com bo cork thiled for magnitude by a zegulator in the din Ilno ard for duration

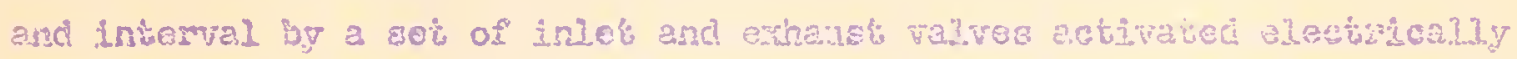
k by a tining devics. The reader is nsferred to paforane 17 20r a conplats description of the equipuent.

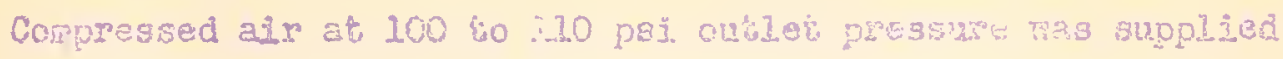
by an air compressos. Fson the compressor bank 8 one-ineh diamoter

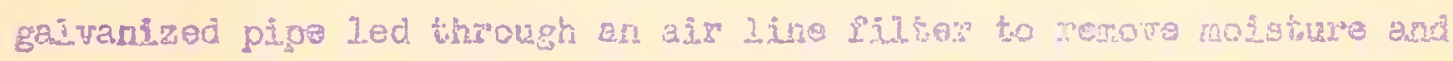

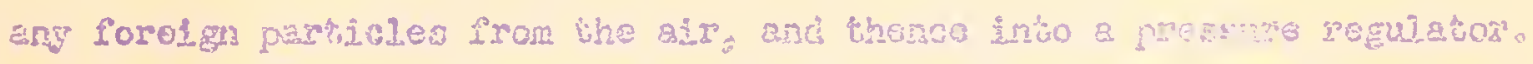

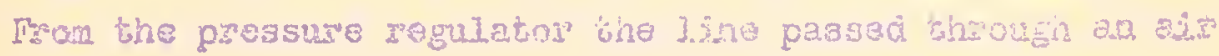

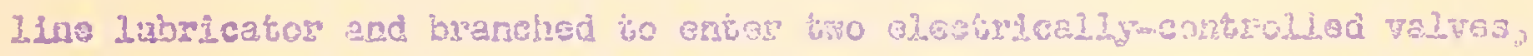

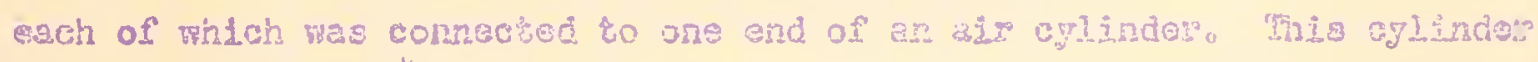

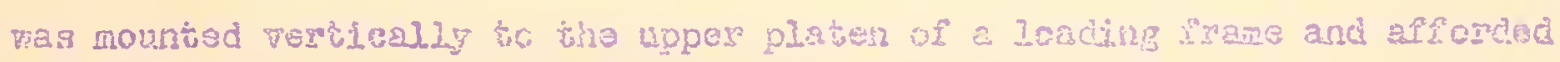
a dommased stroke of fron zGro to two frehos for the loadine Diston. A loading hoad attachod so the Loading piston sopllod load jirsetsy to sanules of etbgrade and base co2ros placed on the lower platan bonecth the ais cglinder. Ang does.ed numbs of loading cycles betrean zero and 99.999 could be prevet b5 moans of a credoremingd counter.

For the sertes cî Fo that only tho 3inglo-neting type of novament of the loading piston Wes used; that 18, the loading piston remained in contaci mist the base course guriace at all times. The axrangemont usod to moasure deflestlose of the subgrace base courso systen utilized a Inoas variable affierentlai transformor with sultablo rocording apparatua (see Flguro 2)。 


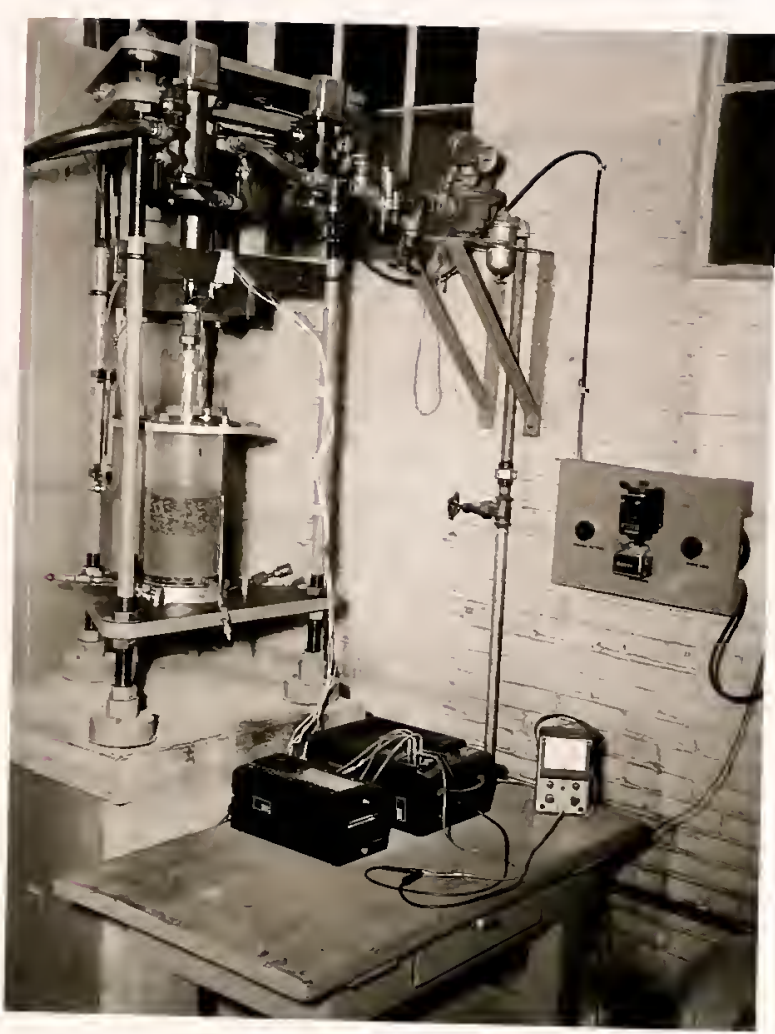

Figo a Hepetithve Loading Euvinoment 


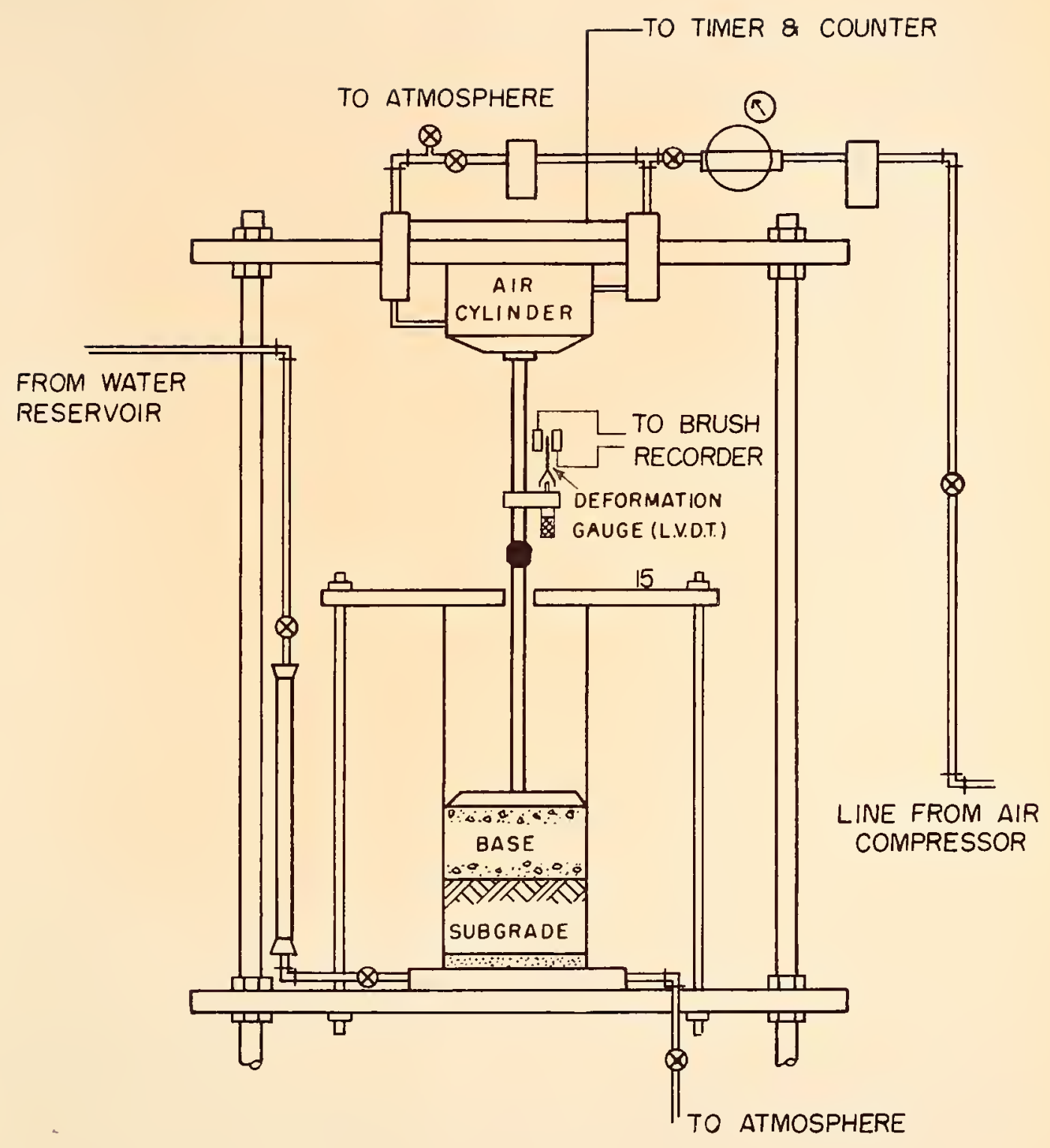

FIG. 2 SCHEMATIC DIAGRAM OF REPETITIVE LOADING EQUIPMENT 


\section{YHIRTAI.}

Sungraje sult

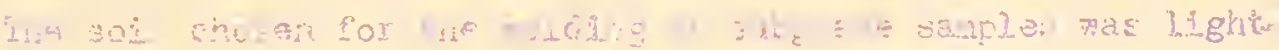

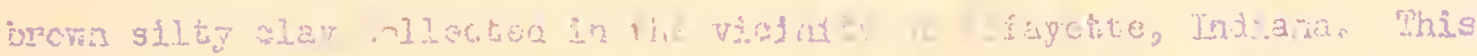

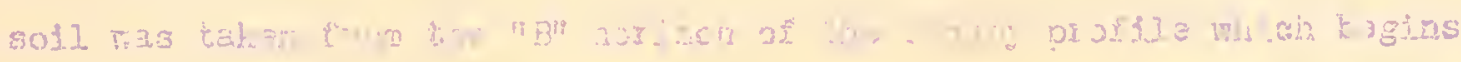

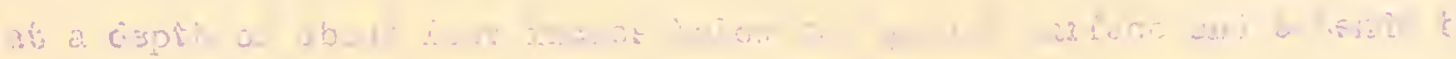

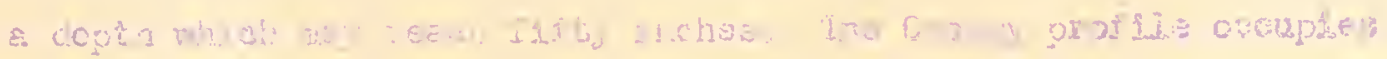

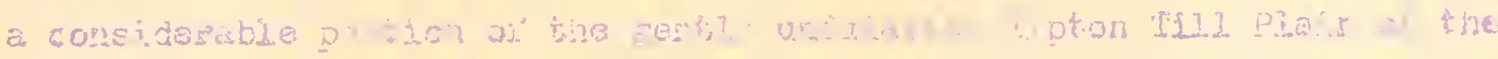

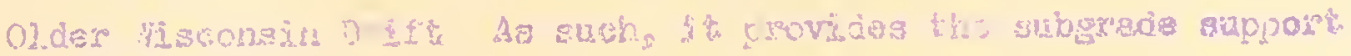

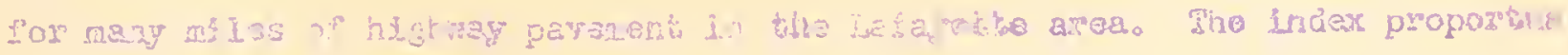

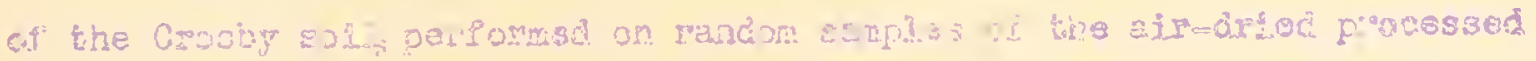

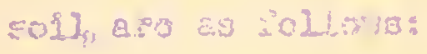

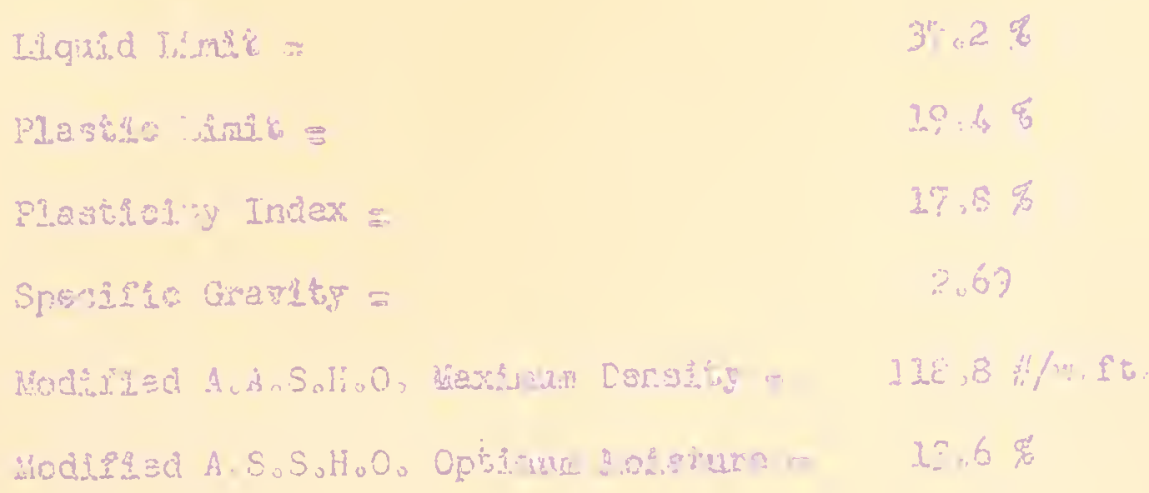

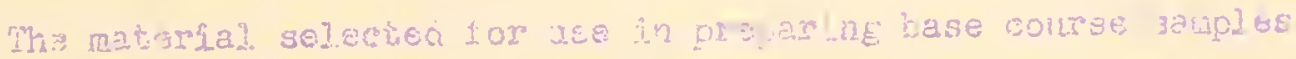

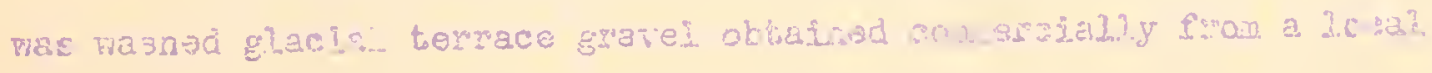
source.

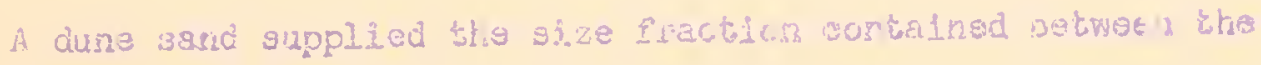




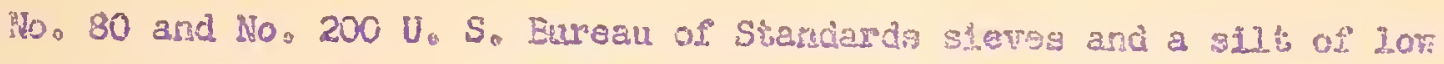
plasticity, podologiealiy classed as Vigo, was used as a minus No. zoo Pilles. The particle shap of the individual gravol pjeces ranged from subrounded to mell-rounded.

Fos" the graded matortalB, trio markm sirce moso solected for etudy 3/4-inch and No. 4. A sot of distrubution curves mas develogod for each maximun aggrogate size, baged on Telbot and Richart: $5(30)$ mathenatical axpression:

$$
p \approx 100\left(\frac{d}{1}\right)^{b}
$$

where "p" Is the por cent of natorta! by waj.ght which pegaes a given

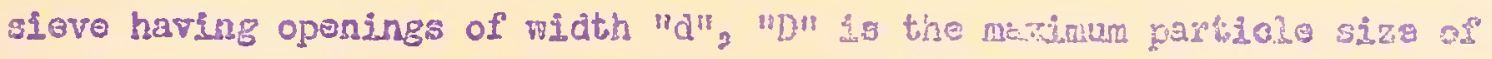
the given aggregate; and " $n$ " is a varoable exporent. If " $n$ " equals $1.0_{8}$ the curve on a linear plot $n 111$ bo a stralght Line. It " $\Omega$ " equals 0.5 . the curve will bo a parabola which pepresents tho lioal trading eurare

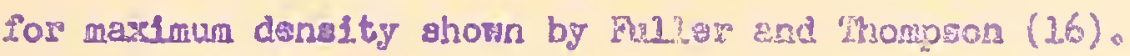

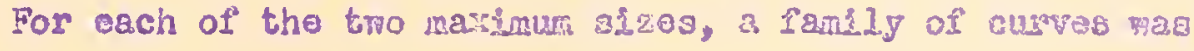
obtainsd by vaxying the exponant $n^{n}$. The gradation curvas seloctoj for 3tudy wero chosen so as to be sourally spaced mith respects to ono anothar and so as to cover the region between the natural Iimitation of unisorats. and tho practical limitation of minus Ho, 200 material. These curvos are shown in Figures 3 and 4 o

In addition, base course samples nors piopared from s. ght d5fioront sands and gravels. By using gmpiss thusly graded, it was possible, to a considerable extent, to ollminate the problers of gagregation inherent in the use of more woll. graded materiale. The nominal size of base course materials used for this sories of tests rangad from $3 / 4-1$ inch to the No. 200 mesh sieve (Sse Figure 7 for actual 3 s.208 used). 


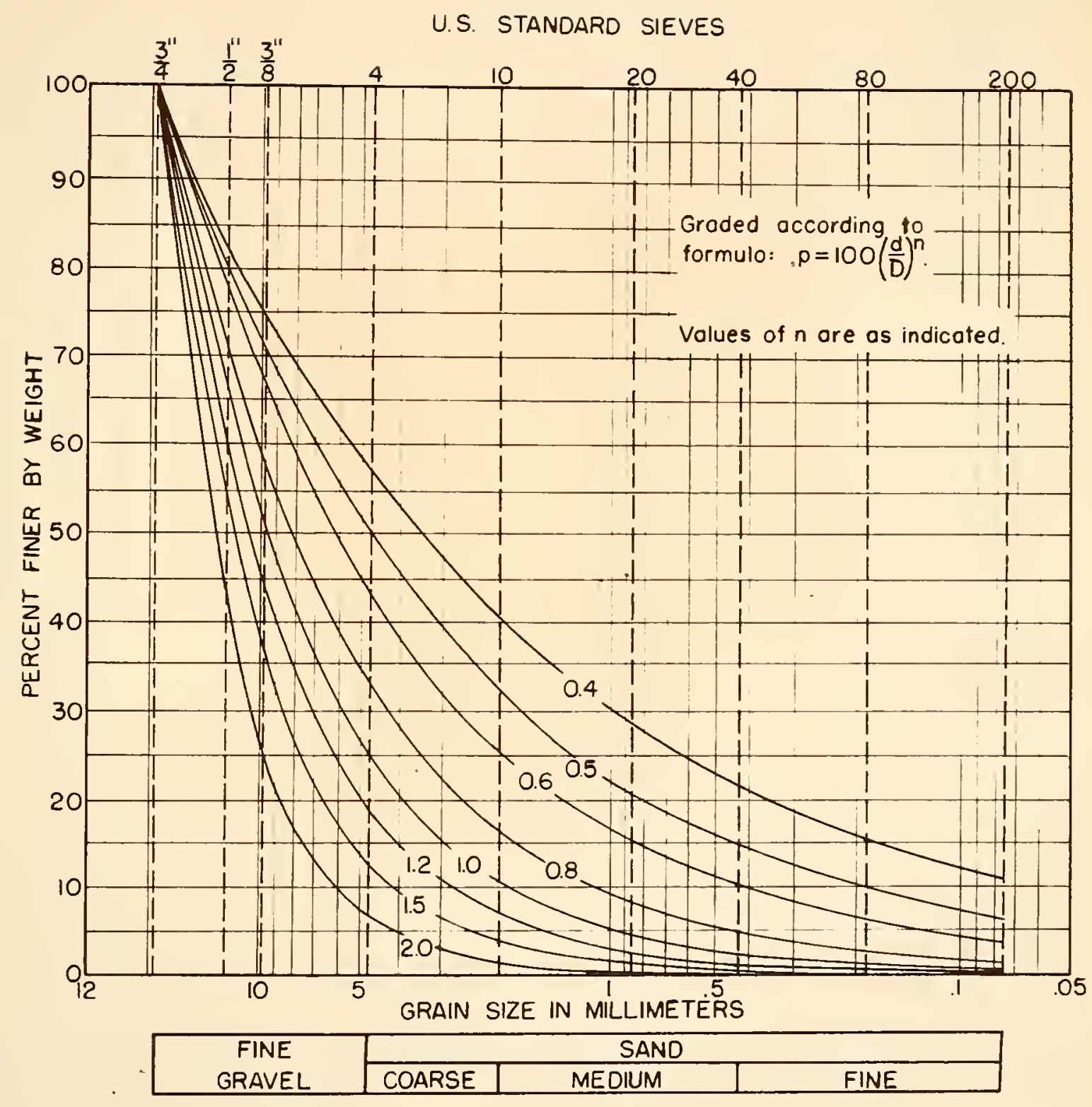

FIG. 3 BASE COURSE GRADATIONS MAXIMUM SIZE $\frac{3}{4}-I N$. 


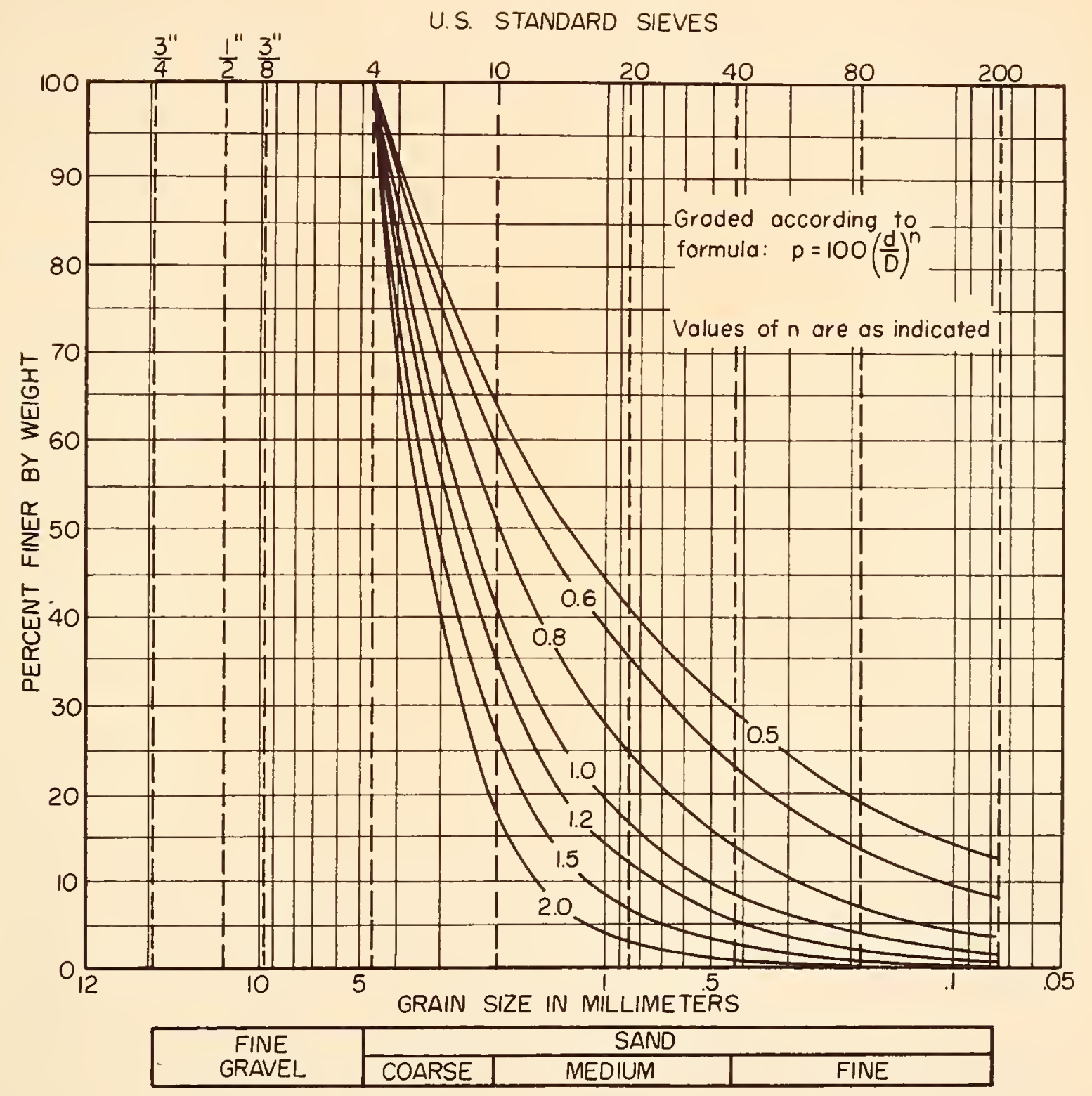

FIG. 4 BASE COURSE GRADATIONS

MAXIMUM SIZE NO. 4 


\section{PROCEDURES}

\section{Compaction Studies}

The procedures adopted for determining index propertios and compaction chaianteristivs of the subgrade soil waro those nomally used by solls angineers.

Moisturdensity relationships were determined for each of the fifieen base course gradations in accordarce with the Corps of Ingineerg' Specification CE 807,1 (13), witich reguires compaction in a 6-inch dianeter mold by a lO-pound hamer falling 18 inches for a total of 55 blows on each of Pive lapers. Considerable difficulty was encountered In developing these compaction curves particularly for the sands whero the effects of kuiking make noisture content vory oritical in the rango of noisture rear the optimum contant. cbvious difficultios arose in attanpting to screed a level surface on the conpaction cylinder where particles as iargo as 3/4-inch mero inrolyod. Since a considerablo anourt of affregate breakaga oceurged in developing these curves, an attempt พnas $21 s 0$ nado to obtaln a maximun vibrated density by vibrating a known neifte of material in a luctto cylinder which was secured to the upper tray of a Gilson Mcchanltal Testing Screan. The apparatus used to determine these vibrated densicies is shown in Flgure 5.

During the vibreting process, a surcharge weight of 80 pounds mas applied to the surface of the subnerged sample. The samplo was vibiated in increments of ten seconds, vertical measurements being taken after each ten gecond interval until a maximum donsity was attainod.

Each baso courze gradation was subjected to two vibratory tests of this nature and the greater density value of the two taken as the maxi- 


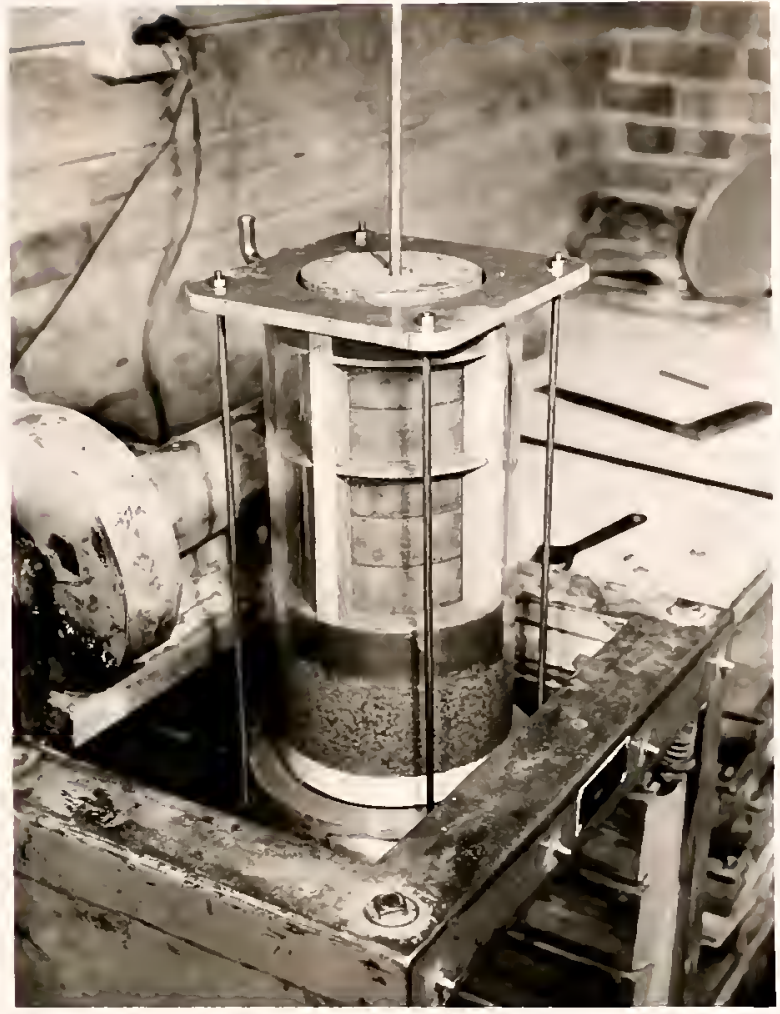

Fign 5 V1rorated Denejt" Apparatis .ic unted

In The Glbeon hechanieal Toghtag Sereen 


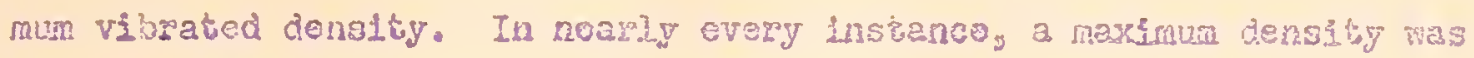
attainod within 90 seconds and in most cases mithin 60 seconds. Grasn size analyses of vibrated samples indicated that thlo short tam of vibsation caused a minimun of aggregate breakage even in tha most open graded samples.

ilinimum densities of base courge naterials nere cletermined by pourlig samples loose into a cylinder of known voline, the smalies value of three trials being accopted as o mininum censidy value.

\section{Repet it Ave Loading Tests}

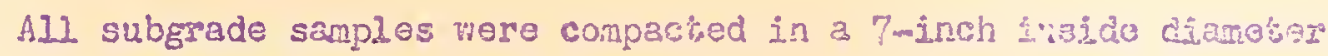
luc?te cylinder to 90 per cent of the maximum density obtainat by folloming the modified A.A.S.H.O. orocedure, To accomplish compaction of the subgrades the moisture contents of the soil was adjusted to the optimum value, and the soil compacted statically from both ends to a helght of four incres at the required density. Compacted subgrade samples wors then permutits to absorb water for a period of 50 hours prior to placing the base cours,

In order to provids a gignificant basks for comperison of bass courso samples, it was decided to utilize the conceptr of relativo densiby rather than compacting the base course samplos to some arbitrary percentage of a dyranic compactive test.

For simplicity, the relustve ciensity of a compactod sample was expressed in terms of density ratio, $D_{\text {Yos }}$ given by:

$$
D_{r}=\frac{d_{n}-d_{0}}{d_{100}-d_{0}}
$$

where $\mathrm{in}_{\mathrm{n}}=$ dry density, pef, of compected specinos,

$a_{0}=d r y$ density, per, loosezt state Irom laboratory cost for rainimum consity; and,

$\mathrm{d}_{100}=$ dry density, pef, maxinum feasible densiby obtained in the laboratory. 
This expression is analogous to that proposed by Lane (25 and io similar to Terzaghis relative dsns1ty (31, pg。27) but has the advantage thit specific gravity of solids need not be determined. The two yield results, which are quite similar, as shoms by Lane (25)。 The concopt of density ratio, as describod above, was used in this study.

It was decided to compact base course samplos to a density ratio of 90 per cent, which night be consiciersd a minimum reouirement in order to líit objectionable consolidation and settlement under hoavy traffic loads, At the completion of tho subgrade soaking period, the base course material ma carefully placed in twc aqual layers onto the compacted subgrado surface inside the lucite cylinder。 Fach layer was then compacted to a height of two inches by, flrst, tamping lightly with a 20inch diameter, 5.5 pound tamping rod; and, then, by applying several sharp blows with a leather mallet to a compaction head placed on the base course surface.

The combined baso coursamsubgrale sampe was next placed in the repetitive load apparatus. Before testing mas comenced, the base course wis saturated from above and the porous stone upon which the subgrade rosted mas saturatad from below under a positive hydraulic head. at all times during the test, the water level in the lucite cylinder remained at or above the base coursa surface.

The repetitive loading apparatus was preset to deliver a 25 ps1 load of 0.3 second duration to the base course surface every four seconds. A total of $40_{8} 000$ repetitions of this load was a!plied to each subgrado base course combination. Periodlc measurements of the permanent and elastic deformations of the system ware made throughout each test by means of a linear variable differential transformer (See Figure 2). 
As each tegt tuas corpleted, any material thal had bean pumped above the surface of the base course was semored, dried, velghed, and subjected to a sieve analgsis. For the more opon-graicd samples, note vas taken of the sxtent of subgrade intrision lnto the base sourse, if discernable. The entire samplo was then extruded by means of a scremjack. and grain size analyses nere performed on the base course to doteritine any changeg which may hevo occurred in lts gradation. 
The rosults of the denstty and repatitsive loading teste on the twenty-three subgyadmaba courge combinations considerod in this study are sumagized in the followling figures and tables. Flgures 6 ard 7 show the resilits of lensity tegts porformed on onch base course sample. Yaluss of maximun and nirinum dangily sie plotiod againot the logarithno of the " $n$ " alues for tho graded aggragates and the logerithro of the grain size for the untiom aggregares

In Figures $\varepsilon_{3} 9$, and 10 tho total deflection (pormanont pius olastic" of each semple is plotted as an ordinate against the logarithm of the number of lcad applications. In each caseg deriection readings were rot comenced until after 100 applisations of the 25 psi load in or.

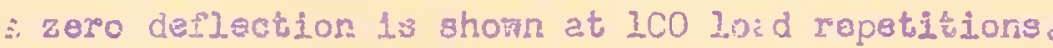

At the semination of sach liest, grain gize analgses woro paro forned on different portifors of the beio course sample or, as in a few casea, on the base course as a rhole to determine any chango in gradation

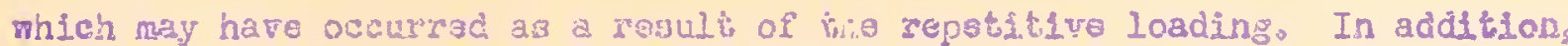
a graln size analysio mas porormed on as.y material which had been pumped to the top surface of the base course. from these data the increase in minus No. 200 matersal in the base course, the welght of minus No. 200 materlal noved to the top of the base courses and the increaso in minus No, 200 material above the subgrade pere computed and recorded in Tables $1_{8}$ 2, and 3 .

The transparent. Iucito ojlinder"s which vas usad to conflne 


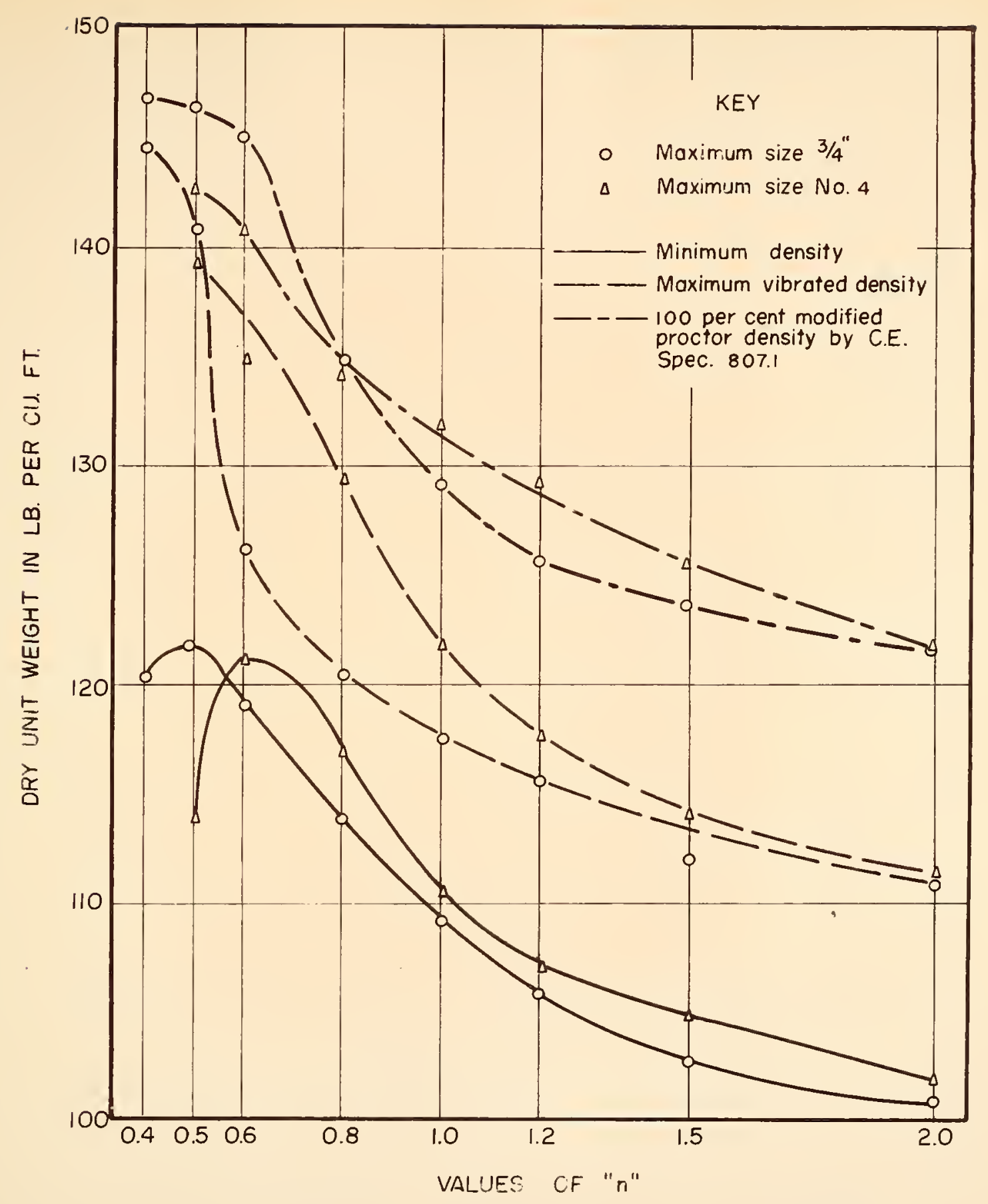

FIG. 6 COMPARISON OF DENSITY VALUES FOR DIFFERENT BASE COURSE GRADATIONS 


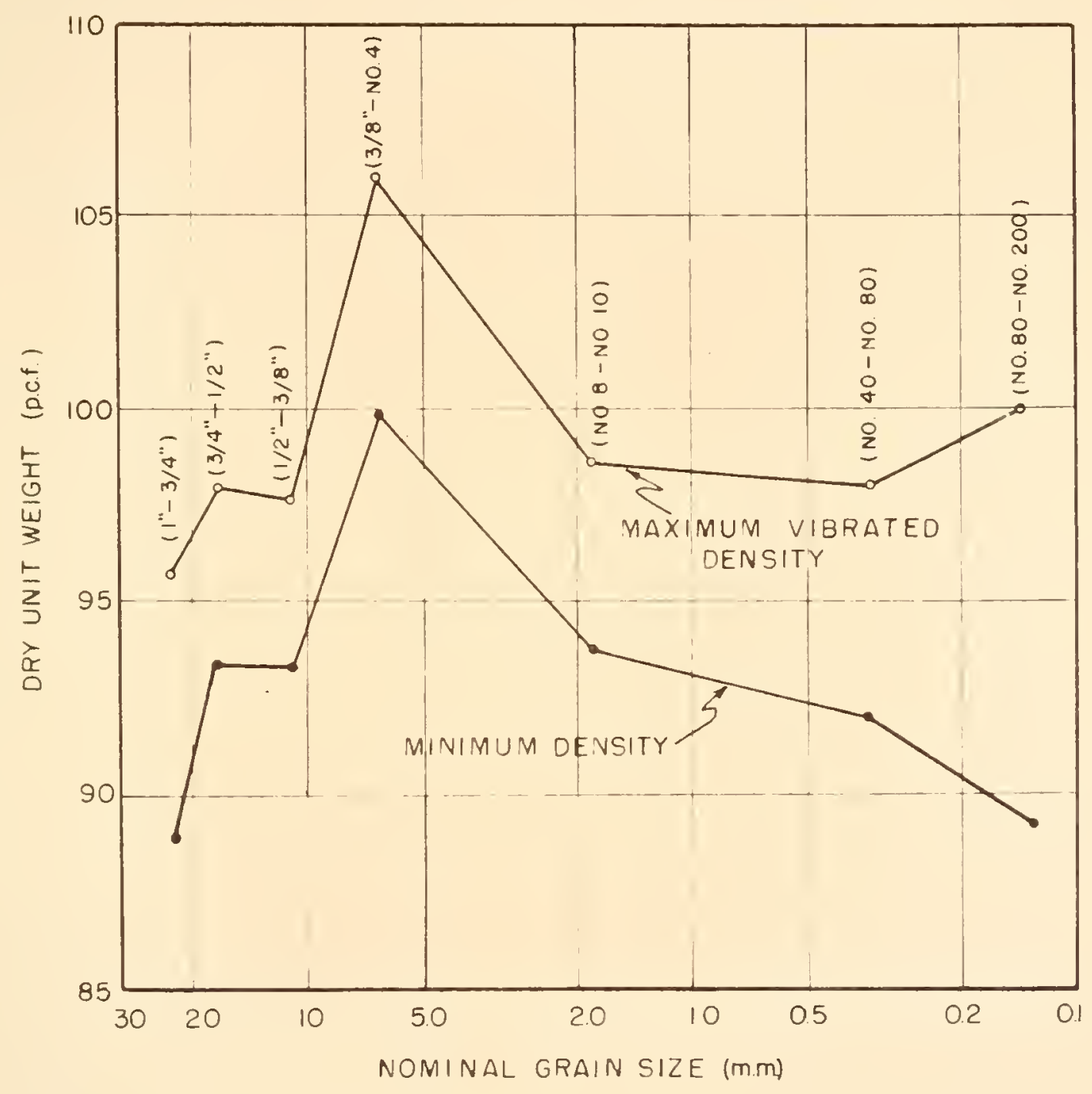

FIG. 7 DENSITY VALUES OF UNIFORM GRADED MATERIALS 


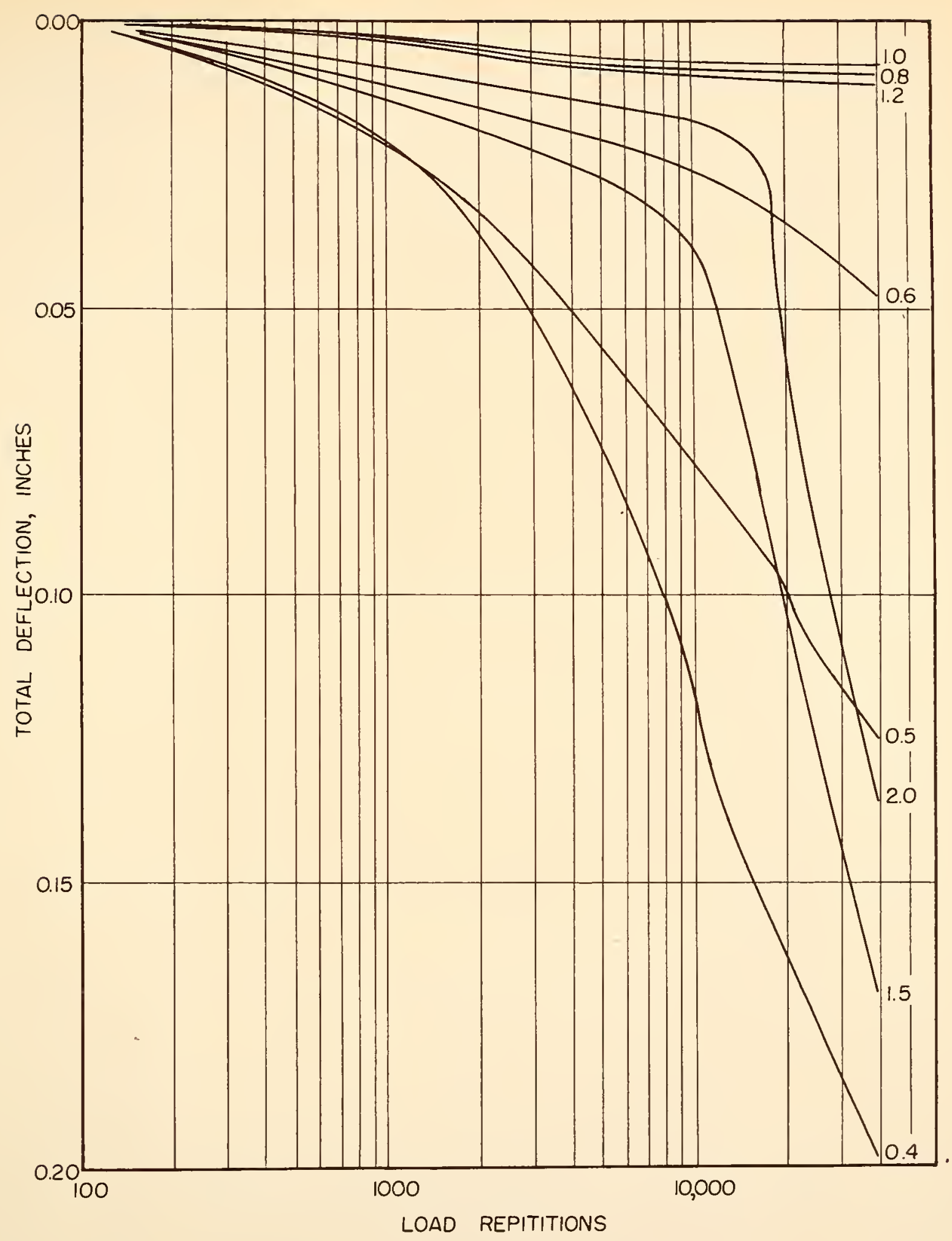

FIG. 8 DEFLECTION CURVES FOR SAMPLES WITH GRAVEL BASE COURSE 


\begin{tabular}{|c|c|c|c|c|c|c|c|c|c|}
\hline \multicolumn{2}{|c|}{ 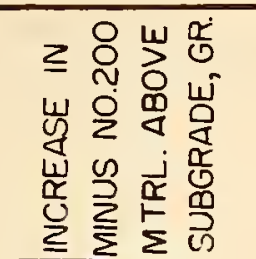 } & $\omega$ & $\underline{1 \Omega}$ & $\underline{I}$ & $\nabla$ & $m$ & $m$ & $\stackrel{\widetilde{U}}{\mathscr{N}}$ & $\underline{\underline{\Omega}}$ \\
\hline \multirow{3}{*}{ 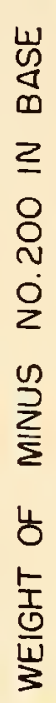 } & 岕岕 & $\frac{\hat{m}}{1}$ & $\begin{array}{l}\infty \\
\infty \\
1\end{array}$ & $\begin{array}{l}0 \\
\text { in } \\
1\end{array}$ & $\sigma$ & $M$ & $\stackrel{m}{m}$ & $\underset{\mathscr{N}}{\sim}$ & 뜨 \\
\hline & 岳 & న్ & $\begin{array}{l}\text { ㅇ } \\
\text { న }\end{array}$ & $\underset{\underset{\sim}{+}}{\infty}$ & $\stackrel{\infty}{0}$ & $\stackrel{\sim}{\sim}$ & m & $\underset{\sim}{\sim}$ & $\overline{10}$ \\
\hline & 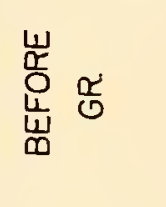 & $\underset{\mathscr{0}}{\mathscr{0}}$ & $\stackrel{\infty}{\stackrel{\infty}{m}}$ & $\begin{array}{l}\text { ঠ } \\
\stackrel{\sim}{N}\end{array}$ & $\stackrel{\nabla}{6}$ & 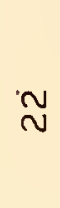 & $\sigma$ & 0 & 0 \\
\hline \multirow{3}{*}{ 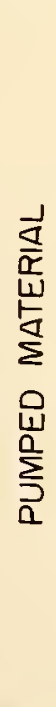 } & 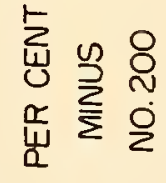 & $\begin{array}{l}\vec{\sigma} \\
\stackrel{0}{0}\end{array}$ & $\vec{\infty}$ & $\begin{array}{l}\forall \\
\dot{\infty} \\
\infty\end{array}$ & 1 & 1 & 1 & 1 & 1 \\
\hline & 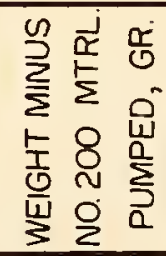 & $\stackrel{M}{\Xi}$ & $\stackrel{m}{\underline{O}}$ & $\stackrel{R}{R}$ & 0 & 0 & 0 & 0 & 0 \\
\hline & 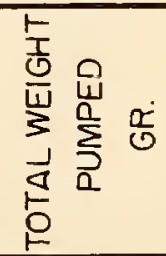 & $\begin{array}{l}\stackrel{0}{O} \\
\stackrel{N}{N}\end{array}$ & $\bar{N}$ & $\bar{\infty}$ & 0 & 0 & 0 & 0 & 0 \\
\hline & 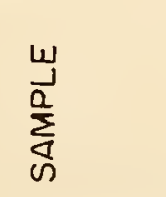 & $\begin{array}{c}\nabla \\
0 \\
m^{+}\end{array}$ & $\begin{array}{c}n \\
0 \\
1 \\
m\end{array}$ & $\begin{array}{c}0 \\
0 \\
1 \\
m \\
m\end{array}$ & $\begin{array}{c}\infty \\
0 \\
1 \\
m\end{array}$ & $\frac{0}{1}$ & $\frac{N}{\frac{N}{1}}$ & $\frac{n}{1}$ & $\begin{array}{c}0 \\
\text { i } \\
i \\
m\end{array}$ \\
\hline
\end{tabular}




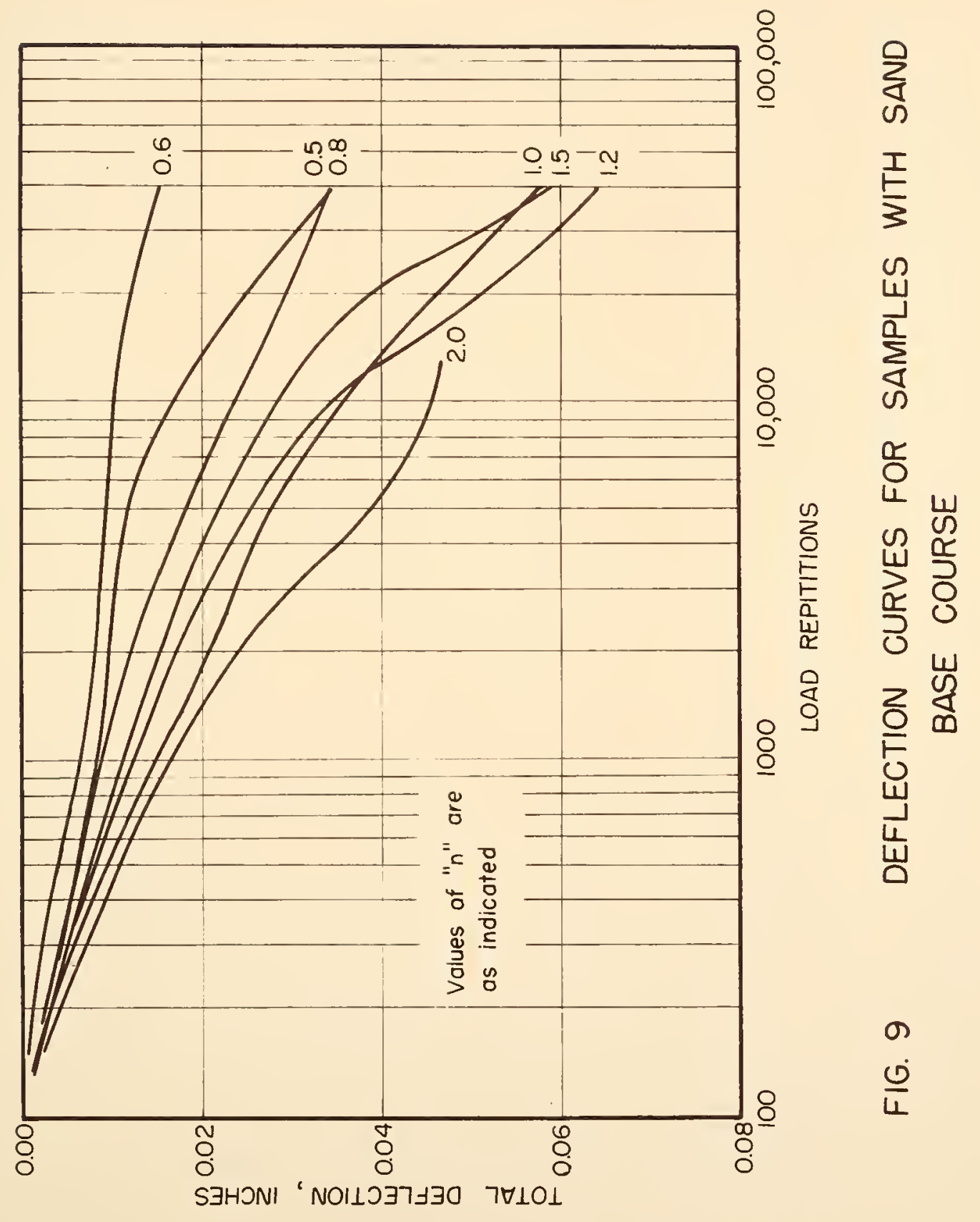




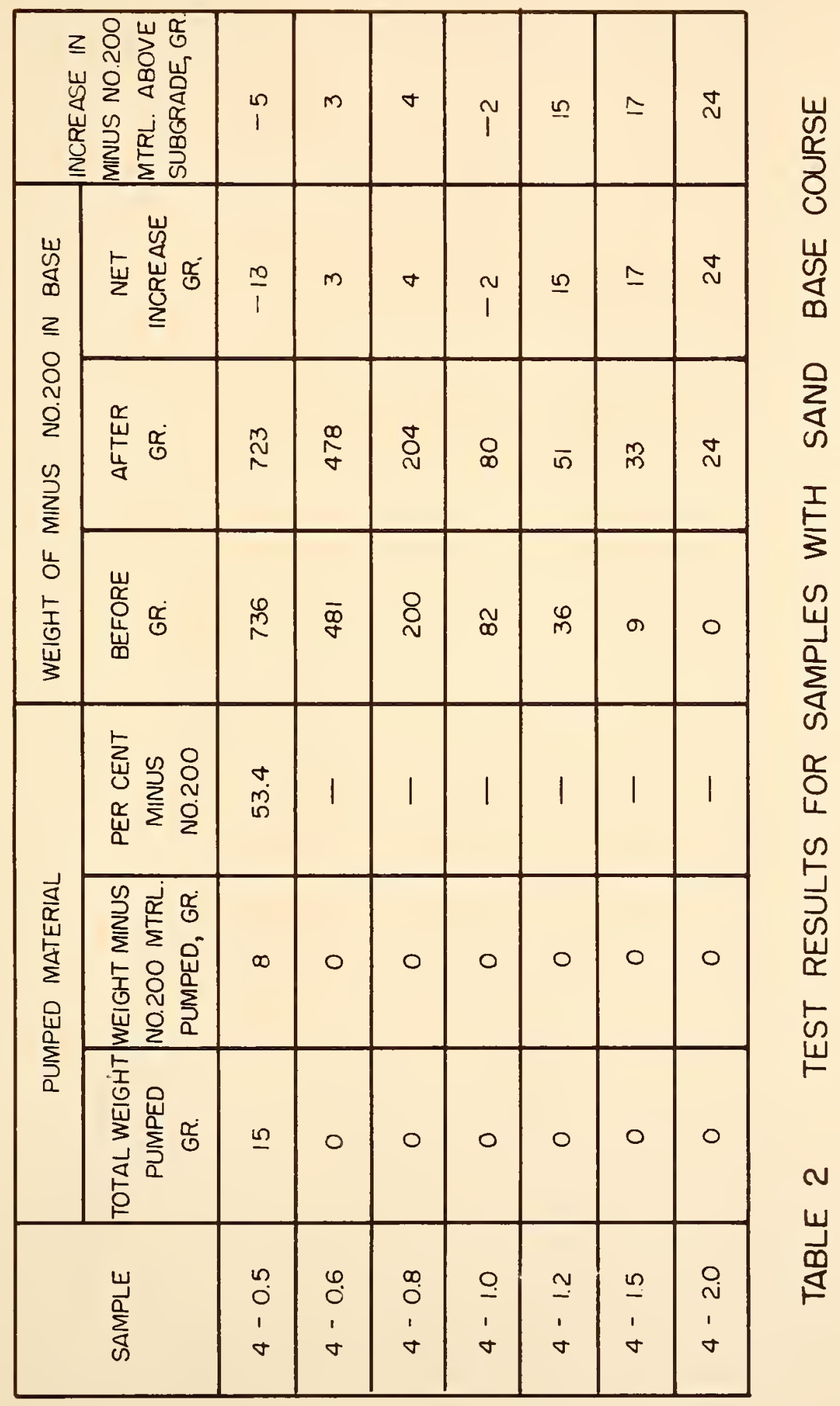




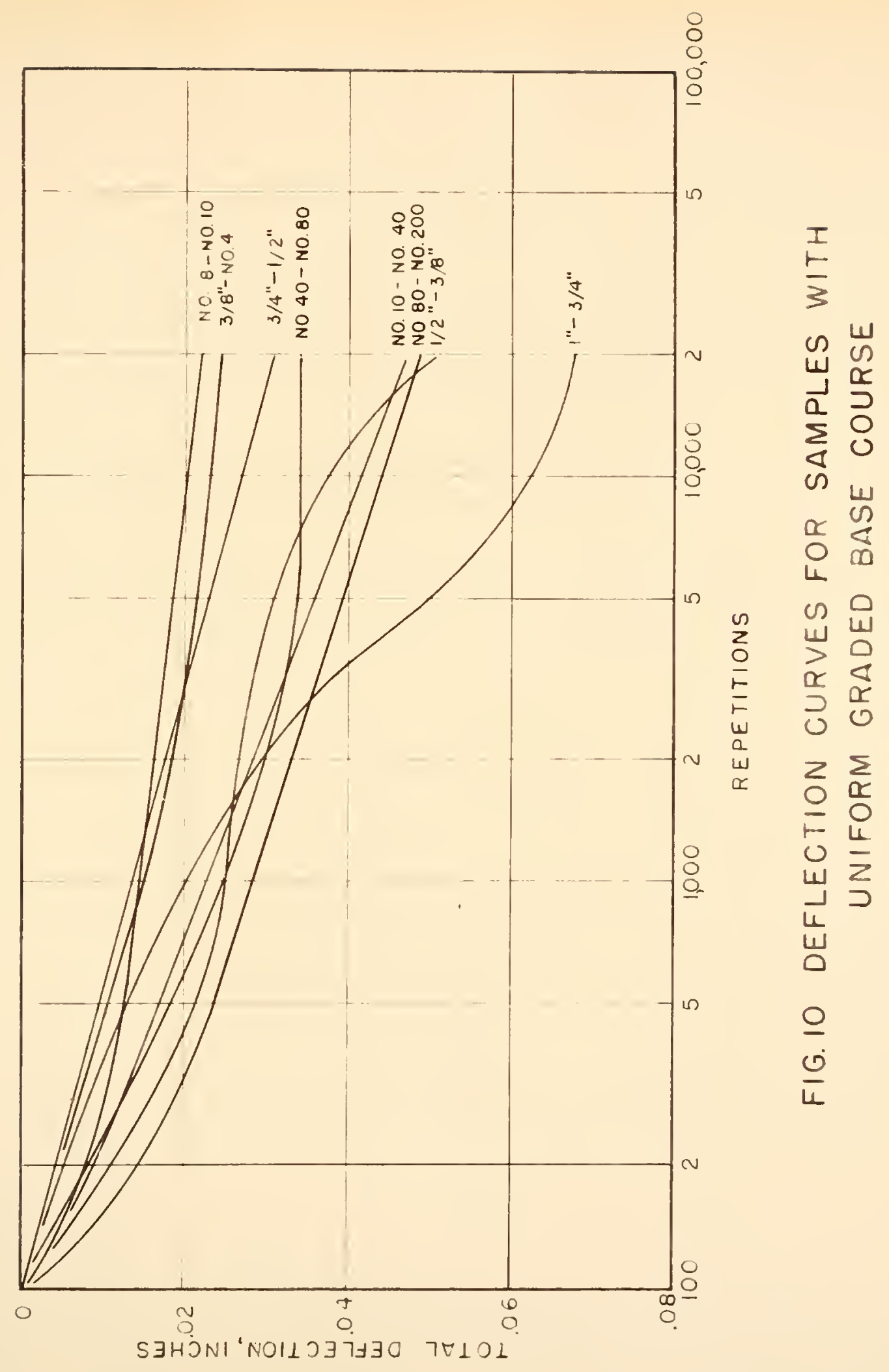


Table 3 Test Results Fon Somplea tTith Unjomancased Bose Course

Serple

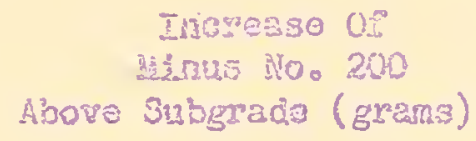

$3 n-3 / 4 n$

$3 / 4^{n}-1 / 2^{n}$

$2 / 2^{47}-3 / 3 n$

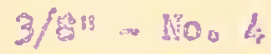

No. $5-180.10$

No. $10=$ No. $\$ 0$

No. $40=$ No, 80

$\mathrm{NO}, 80-\mathrm{NC} .200$
$-$

163

95

45

$2 i$

17

20

10 
subgraderbase course samples, pemitted a visual inspection of specimens at any time during the testing procedure. The intrusion of subgrade soil into the base course was considered to be algniflcant in five of the graded samplos and three of the untorm samples. In the three mosto opon graded sands $(n=1,2, n=1.5$, and $n=2.0)$, sutgrade intrusion appoared to be cnly slight, not exceoding $3 / 4-1 / 2$ inch in extentg while intrusion to approxinately $2-1 / 2$ inches was observed in two of the open-o graded gravels $(n-1.5$ and $n-2.0)$. These observations were supported by grain size analyses performed on the base courses afrer testing. Ths pumping of fine soll to the base coluse surface was observed in the case of thres specinens with densograded gratels $(n=0.4, n \ldots 0.5$, and $n=0.6)$ but in only one case whore a sand base course ras used ( $n: 0.5$ ) : and then only to a small degreo. 


\section{DTSCUSSIOR}

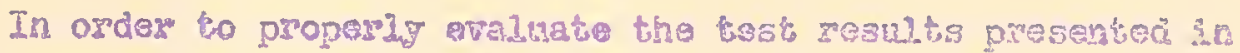
the precoding pagos, it is ossentiel that tho reador bo farjular Fith the framemork of tast conditions in which the repseted load issts wor: perfozmed, the dogree of prectsion obbatned in the proparation of wamples and the accusacy mith which mosulfs nere reastrot. Applied Iosd

Each aubgrademase course semple rus subjectej to repeithlone of a 25 psi load applied at the base courso surface for a duretion of

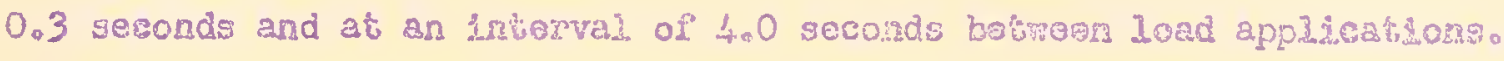
The 0.3 second losd duration was shor enough to appoxamate the

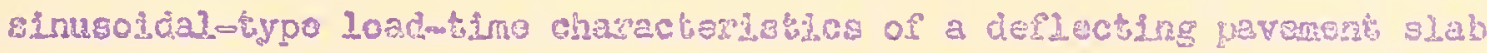

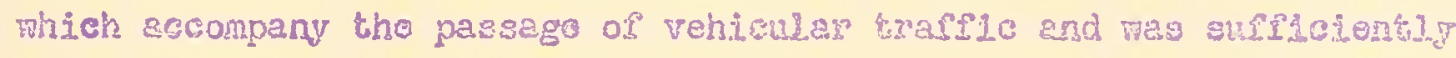
Long to allow dovolopnene of the full 25 pgi load bafore grelease. A 4.0 second interval was also thoro than adegrato to $213 \mathrm{~cm}$ conpleto ralease of one load beforo the applacation of arother. A load Intensity or 25

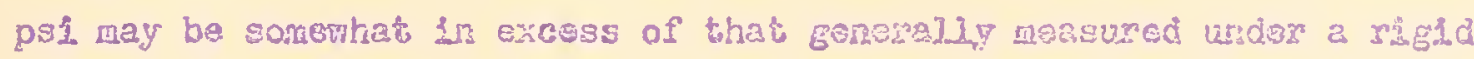

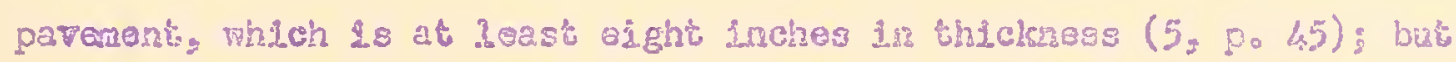
16 was chosen in order to magnify differences in pertormanco boùgen

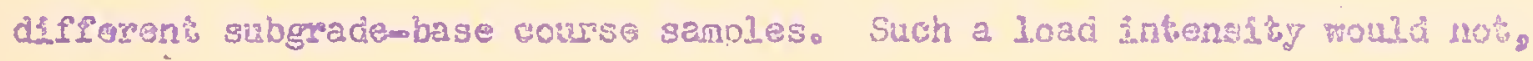
howevor, bo unreasonablo for tho congtruction poriod, which time risy bo crttical in many respacts fron the stanopoint of orereli pavensht perfounance and quality.

\section{Subgrado Compactiog}

A1] subgrade samples mere compacted to epproxinately 90 peì conti of the raximum dry unlt melgit obtained by the modifled A.A.S.H.O. tost (2). The Corps of Engineers, U. S. Army (9) requires this dogroe of corapaction 


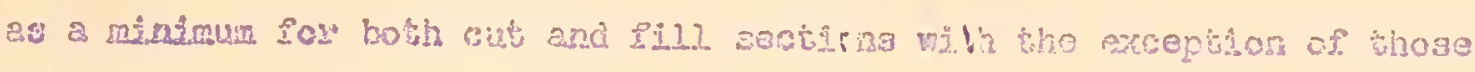
composed of cohosionless sand Tho recitrenerl, homever, may be olighty

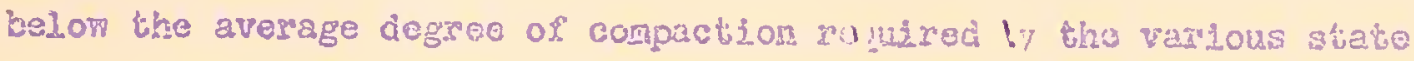
highway dopertmentio

\section{Baso Cousso Compaction}

All bage courso semples nore enparted ro a dorsziby rablo of 90 per cent which involved dotermination of the ralues $d_{0}$ arid disoo Tho Talues obtained for minlnum dexsity, $a_{0}$; cas bo wonsidered as highly

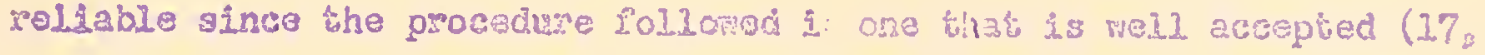

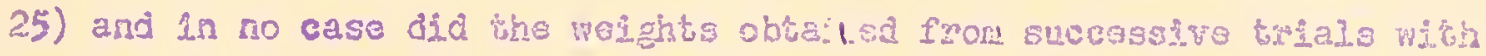
the same sample vary by rore than 0.06 , nds. Determination of maxinum

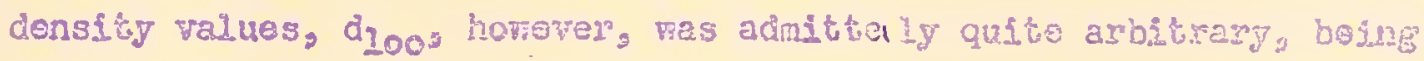
in each sase an average of the maximum mod: Led A.A.S.H.O. dry unht molght (according to CE Spse. 807.1) and a nisum dry unit wsight obtained by a procedure of nechanical vibresto:

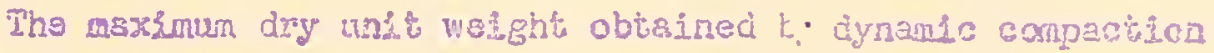
accoraling to CE Spee. BOf ol has barn in the past vicon for dyoo (17)

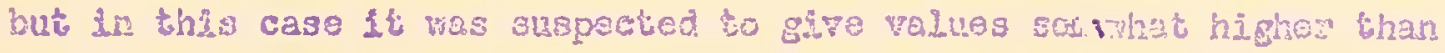

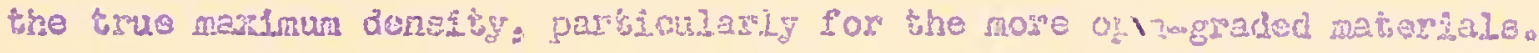
The drnemie conpacton ured is a rather severe tost, cau ving a nsasidezable amount of aggregate breaktags such that tho deneities obisind are not shose of the original gradation but, zather, of some non greiation resultm Ing fion an alteration of the orizinal naterial. Sholburise ( s) showed that the breakage of aggregate dus to mlxing, lolling, tratelo, ind tho Los Angeles Abragion Iest resulis In greciations which tend to app: ach Fuller'g curve of araxinum density. This sane tondency could be privinfal to exist in the dynanic compaction togt. If so, it roula be reeconel. ? 


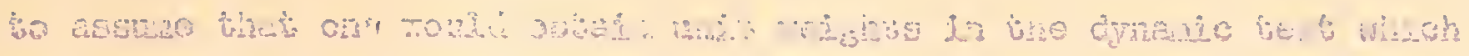

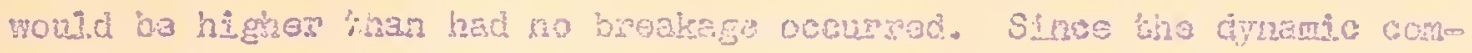

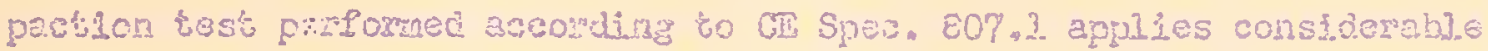
agitation ani compactivo affort to a granulaz sarale, it ks corcoivable

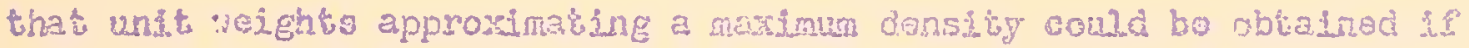

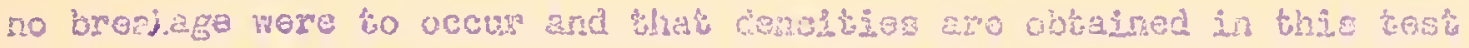

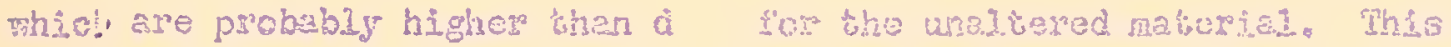

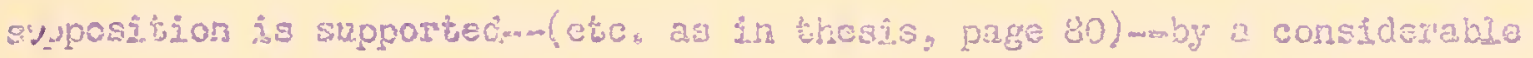
enount.

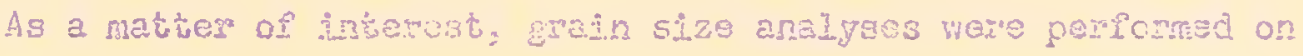

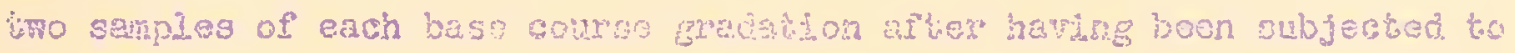

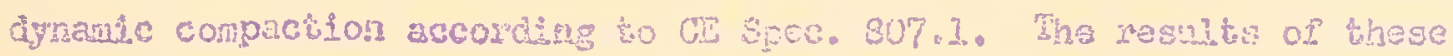
andyges are shorn in Tabje 4 as a tabulation of lncrease in per cort:

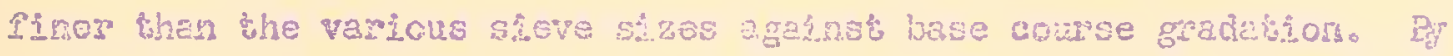

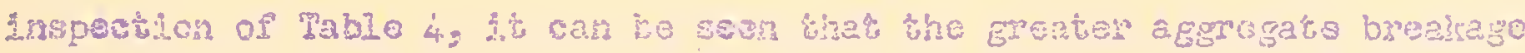

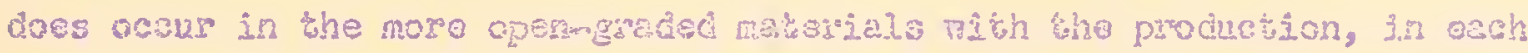

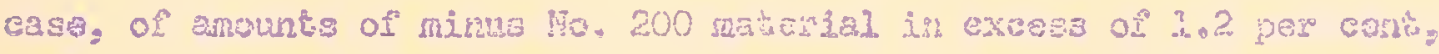
and In nosto cases noto.

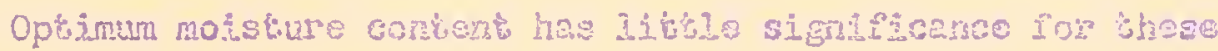

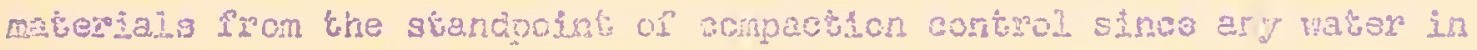

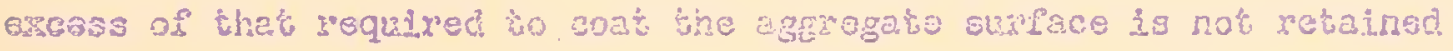
but meraty passes through tho sande. These observations plus tha

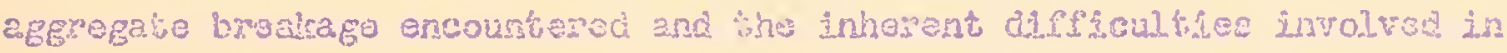
dovalopirg compacton enves for this zort of material strongly supporst she

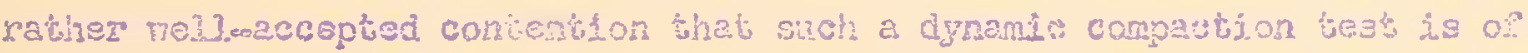

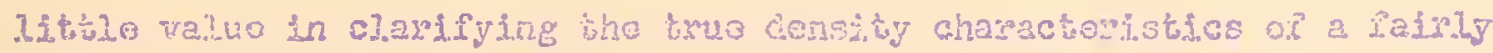
clean graniag material.

The vibrated denstut best which was used, on the oiner hand, was belisved to give values thich were lower thas true naximus densisy. 


\begin{tabular}{|c|c|c|c|c|c|c|c|c|}
\hline \multicolumn{3}{|c|}{ MAXIMUM } & AGGRE & TE $S$ & $\frac{3}{4}$ & $\mathrm{CH}$ & & \\
\hline \multirow{2}{*}{$\begin{array}{l}\text { INCREASE IN } \\
\text { PER CENT } \\
\text { FINER THAN }\end{array}$} & \multicolumn{8}{|c|}{ VALUES OF " $n$ " } \\
\hline & 0.4 & 0.5 & 0.6 & 0.8 & 1.0 & 1.2 & 1.5 & 2.0 \\
\hline $3 / 4 \mathrm{IN}$ & 0.0 & 0.0 & 0.0 & 0.0 & 0.0 & 0.0 & 0.0 & 0.0 \\
\hline $1 / 2$ IN & 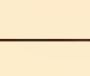 & $\longrightarrow$ & $\longrightarrow$ & 0.4 & 5.6 & 9.7 & 12.0 & 9.9 \\
\hline$Z_{B}$ IN & 2.3 & 0.2 & 4.2 & 6.1 & 12.1 & 15.5 & 19.2 & 11.9 \\
\hline 1.0 .4 & 3.6 & 3.1 & 6.0 & 8.3 & 12.1 & 15.7 & 19.6 & 11.9 \\
\hline NO. 10 & 1.1 & 0.5 & 2.1 & 4.1 & 6.3 & 8.1 & 9.3 & 3.7 \\
\hline NO. 20 & 2.3 & 2.4 & 2.9 & 3.3 & 5.2 & 6.1 & 6.9 & 2.6 \\
\hline NO. 40 & 2.3 & 2.5 & 2.7 & 2.9 & 4.7 & 5.2 & 6.1 & 2.1 \\
\hline NO.8O & 1.8 & 2.2 & 2.3 & 2.6 & 4.5 & 4.5 & 5.4 & 2.0 \\
\hline No.200 & 1.4 & 1.6 & 1.6 & 1.8 & 3.7 & 3.7 & 4.8 & 1.6 \\
\hline \multicolumn{9}{|c|}{ MAXIMUM } \\
\hline NO. 4. & & 0.0 & 0.0 & 0.0 & 0.0 & 0.0 & 0.0 & 0.0 \\
\hline$\therefore 10$ & & 10 & 2.8 & 1.8 & 2.6 & 3.9 & 5.4 & 9.6 \\
\hline NO. 20 & & 3.4 & 3.8 & 4.0 & 5.2 & 5.9 & 6.1 & 7.2 \\
\hline NU. 40 & & 4.0 & 4.9 & 5.3 & 5.1 & 5.8 & 4.0 & 4.8 \\
\hline 110.80 & & 3.9 & 4.3 & 4.6 & 4.8 & 5.0 & 2.7 & 3.6 \\
\hline No.200 & & 1.2 & 1.6 & 2.0 & 2.2 & 2.9 & 1.6 & 2.7 \\
\hline
\end{tabular}

TABLE 4 TABULATION OF AGGREGATE BREAKAGE IN THE DYNAMIC COMPACTION TEST (GRADED BASE COURSE MATERIALS) 


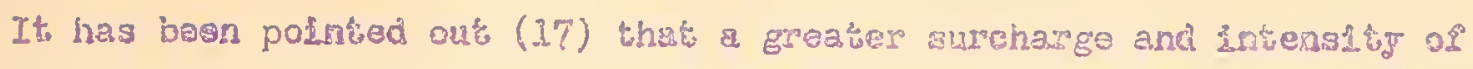

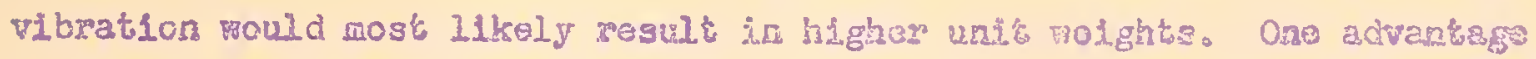
of thls test, however. Iay in the fact that a maxioun density could; in

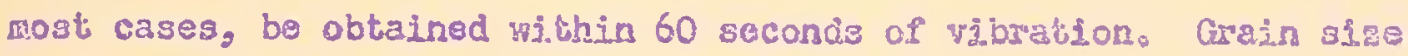
analyseg performod on semplos which had boon vibrated revaaled hhat shis short tem of vibration resulted in only ninor anounts of aggregate broakago.

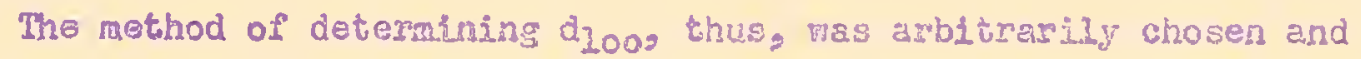
may be sabject to some criticism. Fortunatoly, honever, the degree or base courge compaction was found to have litule djacte offect on the values of the measured variables in such a test (27\%. It was observed In this investigation that the principle effect of a lomer degroe of base course compacion was to cause a greater initial settlemsnt vithin the first 100 or 200 load applications, presumedy, mithin the base course primarily. Thus, axy doformation or lack of deformation whish

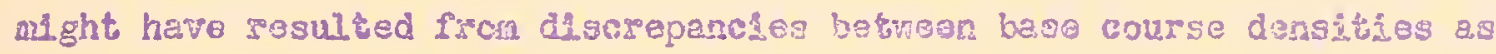
compactod and true density ratio of 90 per cent could very been nasiced by tho pact that dolloction readings were not plotted unts 100 repetitions of the 25 psi. load had been applied.

A comparison of the various denstby values which voro detornlined experimentally is shown in Figrios 6 and 7. It is interesting to noto how eritical, with respoct to attalnable unit woights, a small change in aggrogate gradasion may be within corvain gradational ranges. Heasuremont of Tegt Results

of the values measured during and immediately aftor each sepoatod load tast, the doflection of the aubgradsmbase course aystans nere considered to be the most reliable. AII that was required nas a linear calloretion. 


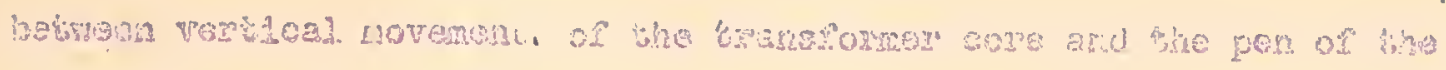

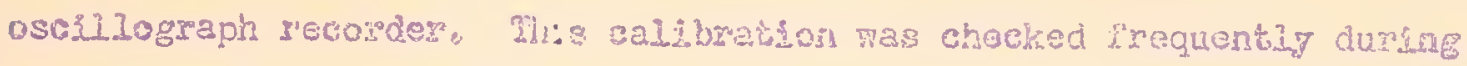

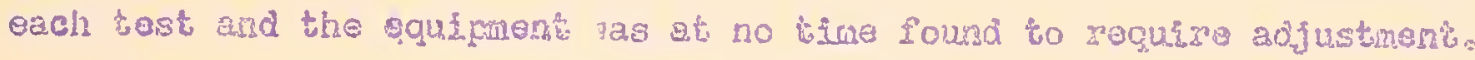
The recordad defleotion, the, wro dependent onlg upon tiso performance

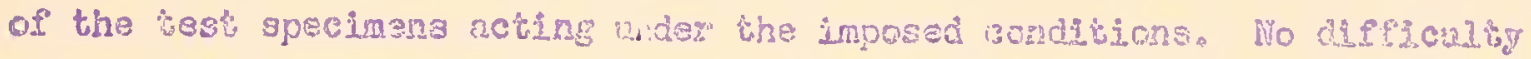

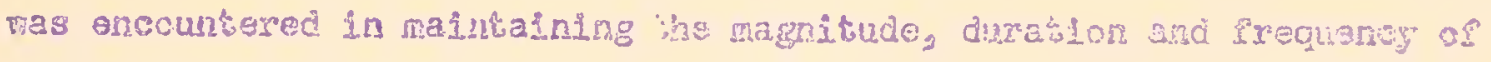

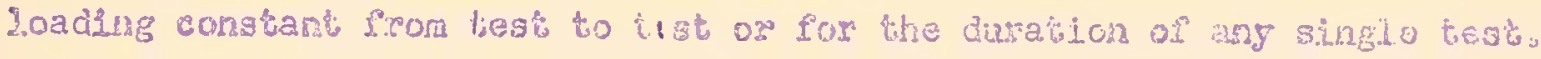

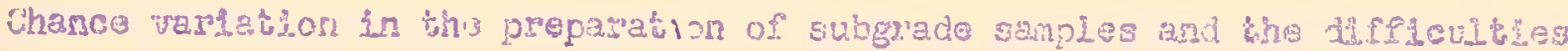

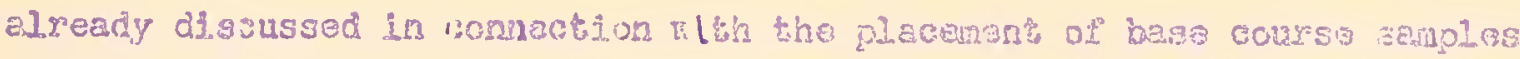

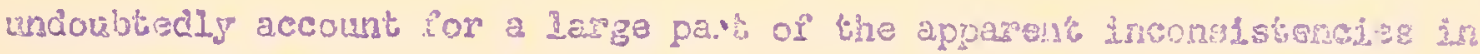
the tost roults.

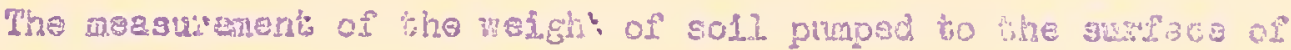

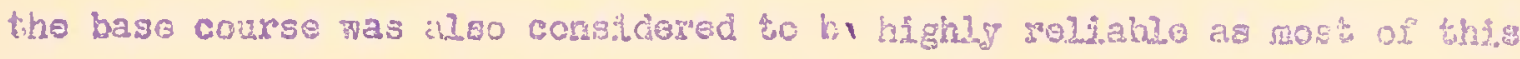

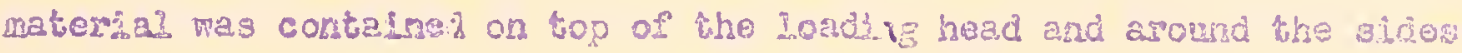
botweas the loading head asc the cylinder that

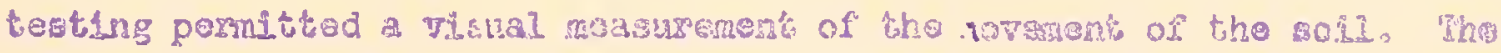

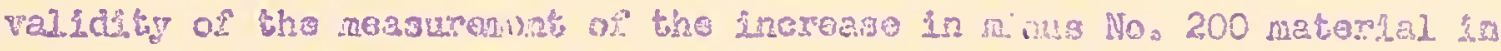

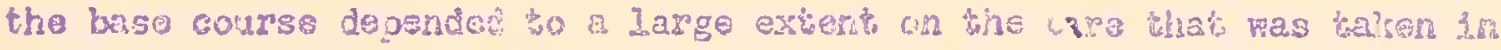

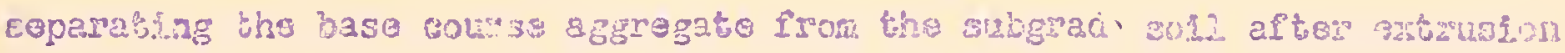

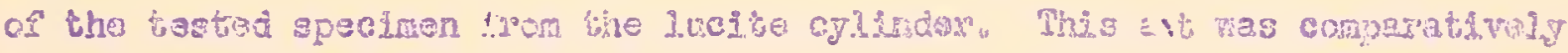
casy to pertorm In the case of spccineng with sand base col'ses whare the

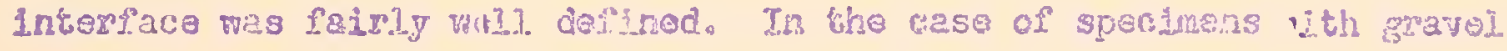

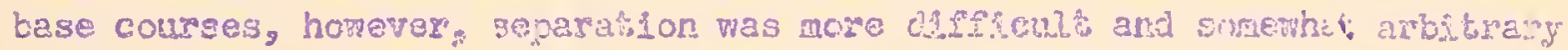
In a fer cases, particuimiy where subgracis soli had been extensiv. Intruded Into the more jpon-graded bases. Intexpretiation of Regulisa

Tho trarisparunt Iucito eglindsr which was used to contain the 


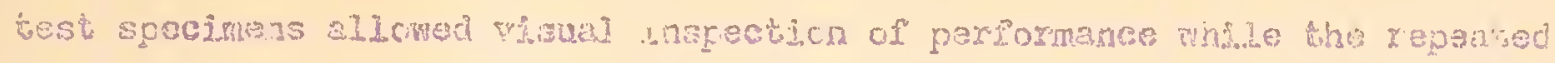

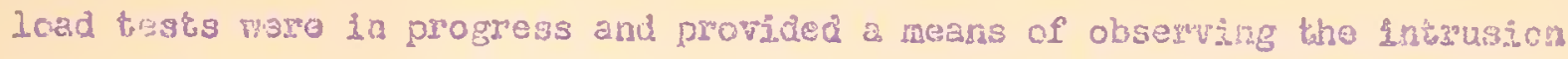
of subgrade soll into the base course and the snovenento of rine soin within the base course to the bass course surface. These otservations vers substantated by deflontom measuremonts mado auxing each test and bs values measured Lnimalatol. arter the complotion of each test.

Test spociners with gravel biso comsea exhishoted punping of Ine soll to the surfece of tho three censax-graded base course samples and Intirusion of subgrade soiI lato the three mose opensgraded. Iho

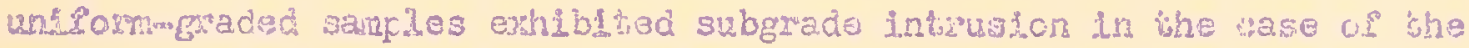

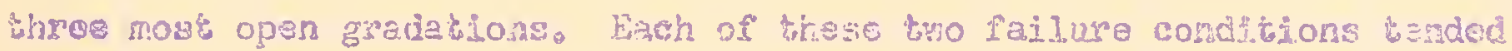

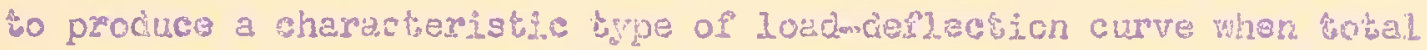
deflections ware plettad a.9 ordinates against tho logeriturn of load repotitions as abscissise If substantial Latrusion of subgrade sold

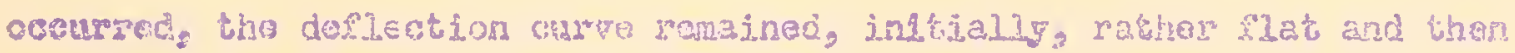

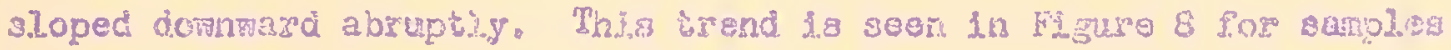
$\Omega=1.5$ and $n=2.0$. If, on the other hend, no Lntrusion occurrea but

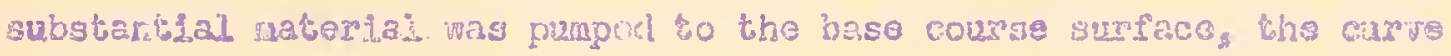

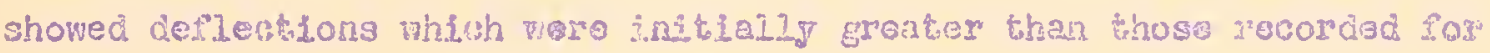

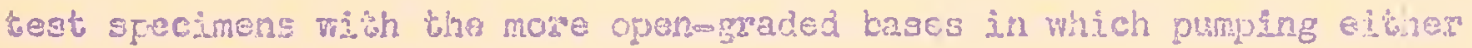
occurred so a lesser extert or not at 211 . This trend nat be sean in

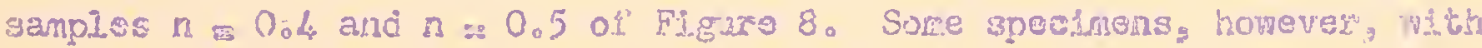
bsse course samplas of an Intermediace gradation exhibited neithes punpigt: nor subgrade intrusion and restitod 13 snaller subgrade-base corr 30 deflections. $\Lambda$ plot of tho deflecrions occurring in each spactinen at

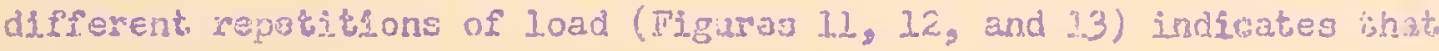
Ghero may be an optimun gradatton phich whon compacted to a high re..at,ivo density over a good subgrade vill wesult in minjum deflections os tho 


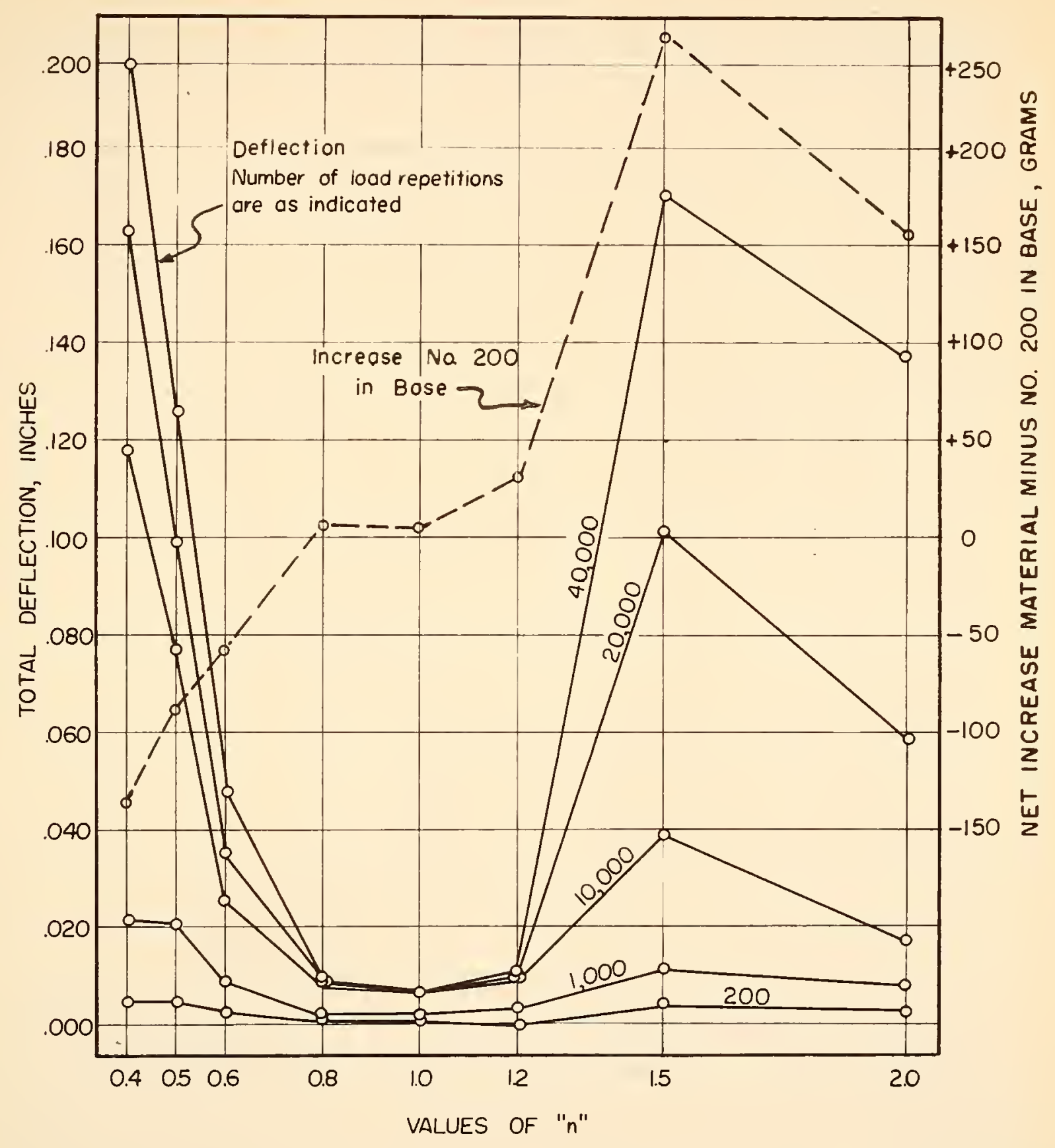

FIG. II DEFLECTION VERSUS GRADATION FOR SAMPLES WITH GRAVEL BASE COURSE 


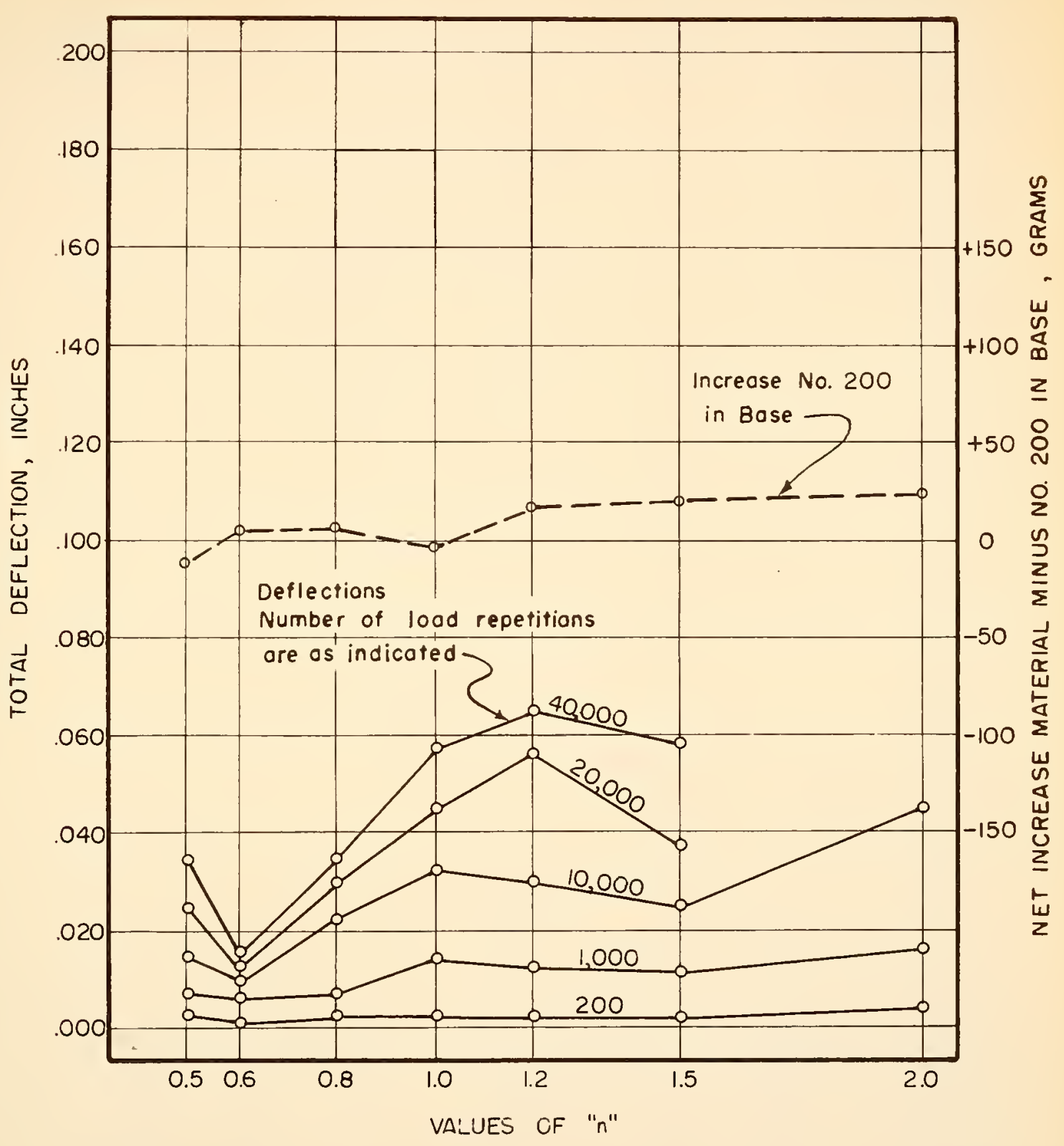

FIG. I2 DEFLECTION VERSUS GRADATION FOR SAMPLES WITH SAND BASE COURSE 


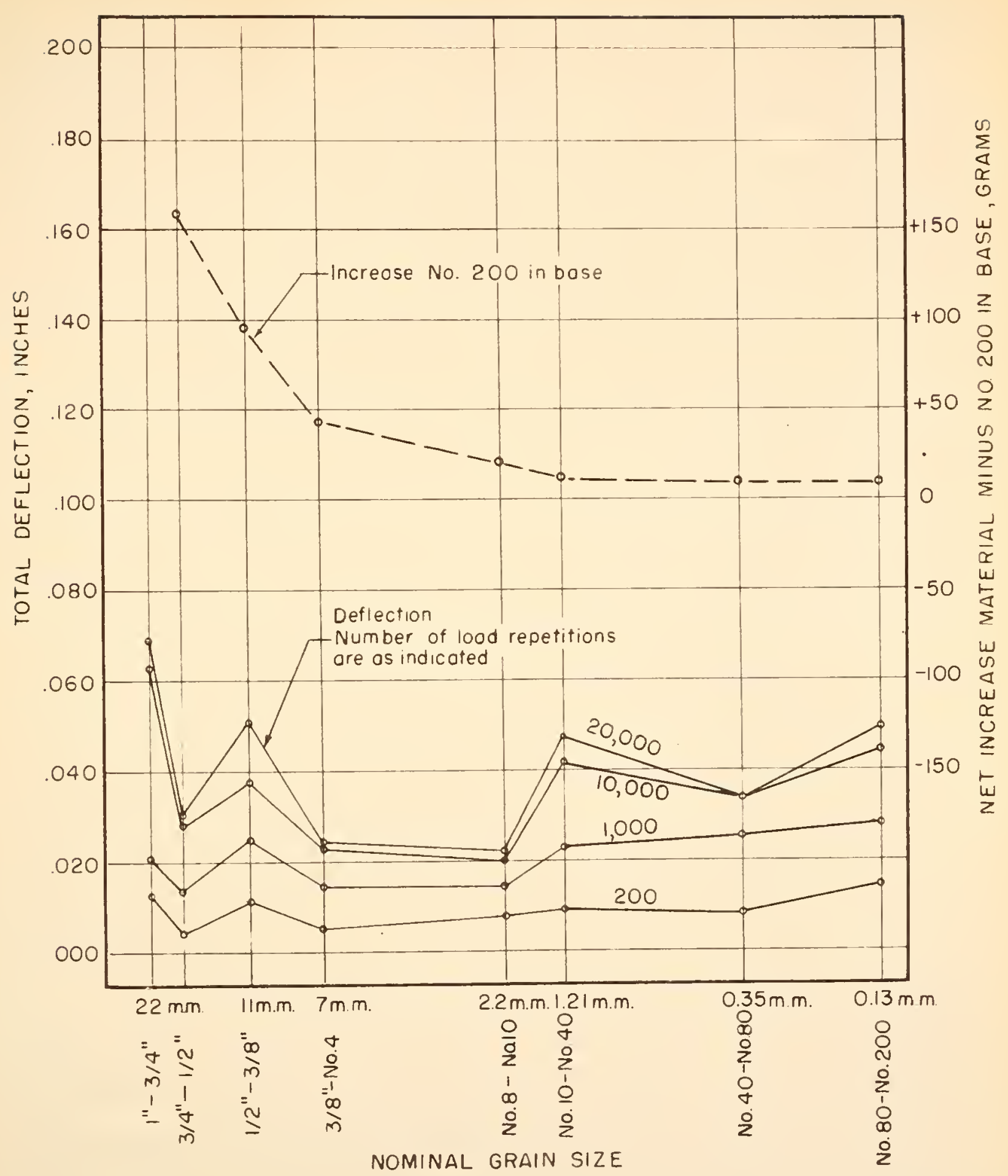

FIG. 13 DEFLECTION VERSUS GRADATION FOR UNIFORM BASE COURSE 
subgracia-base colrse systomo

Ir: 11 cases when spocimens with gravel baso courses wore tested, a rood corse ation was founc betreen large doflections and the naladies of base corrse punping and stbgrade intrusion, and it might be conduded that if 2 base course gradution could be selected that mould rasist these latter tio effects, deflection of the subgrade-base course systen could be held t: a minimum in any given situation and pavemsnt cracking and raulting resu. ing from lask of foundation support might be retarded.

Table I indicates minor increases ir minus lio. 200 soll above the Mbgrade for base course samples that experienced no visible intrusion of subgrade soil (samples $n=0.4$ through $n=1.0$ ). Ihis minus Ho. 200 material was believed to reflect the difficultes encountered in separating tho base course sample from the subgrade soil. One rather obvious inconsistency is that samplo $n=2.0$ showed smaller deflections and ioss increass in minus lio. 200 matexial in the base than did tho Iess open $\Rightarrow$ graded sample $\mathrm{n}=1.5$. This could probably be attributsa in anall part to chance differences in subgrade sample preparation but was felt to bo due mainly to tho great difficulty in obtaining unformity in the base coticso and preventing segregation during placing which was farticularly evident mith tho opengraded gravels.

- In only one cass $(n=0.5)$ did a test specimen with a sand base course exhibit pumping of fine soil fron the base, and this was very minor In extent (see Table 2). In three cases $(n=1.2, n=1.5$, and $n=2.0$ ) a small amount of subgrado intrusion nas noted. This also was shown to be minor in extent by the results of a grain size analysis performed on tho base course sample after testing (Table 2)。 In general, specinens with sand base courses showed less naterial pumped to the base course surface, less intrusion of subgrade soil and amall deflections over a wider rango 


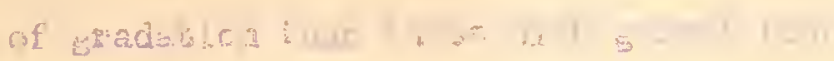

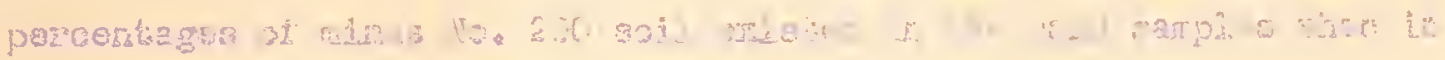

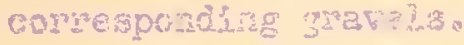

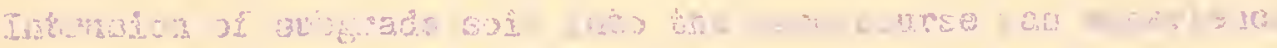

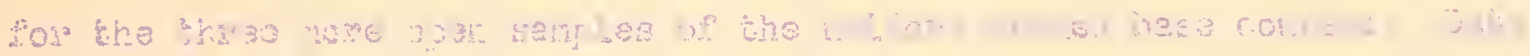

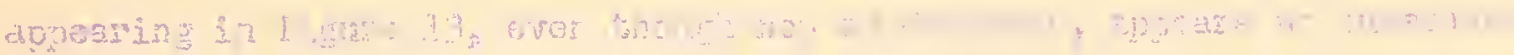

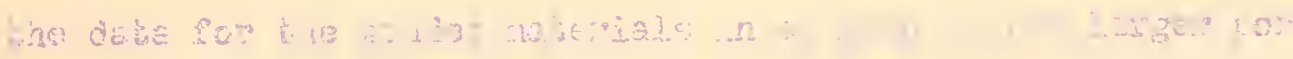

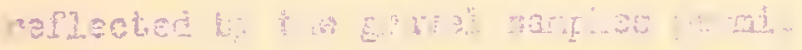

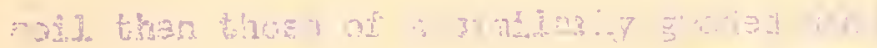

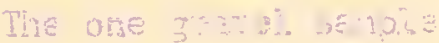

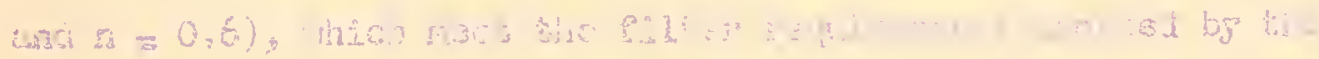

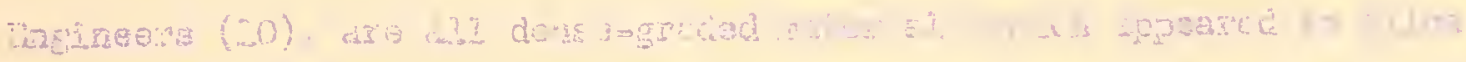

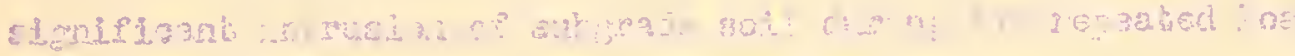

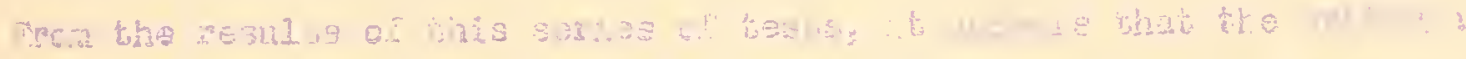

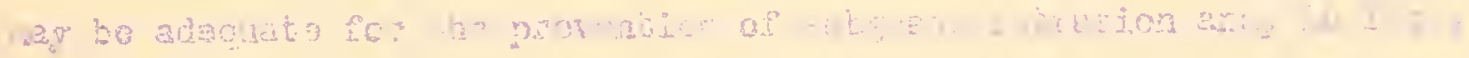

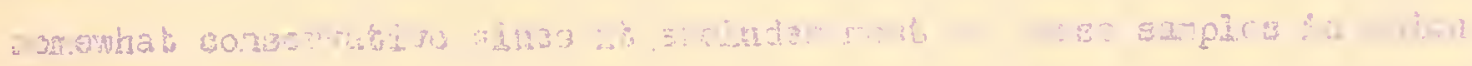

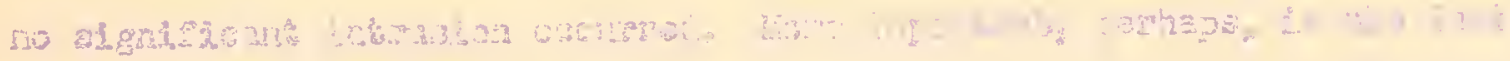

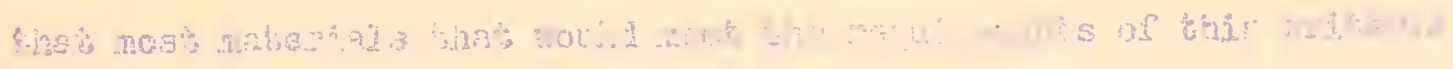

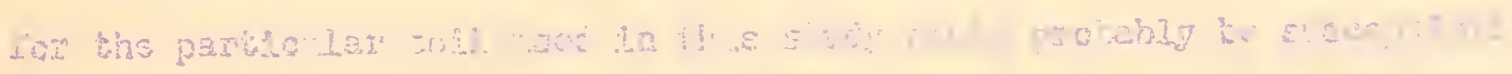

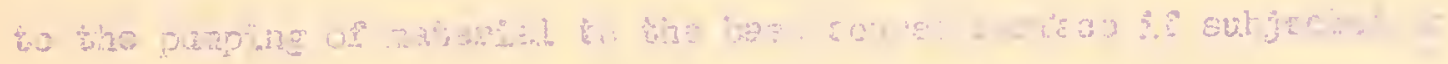

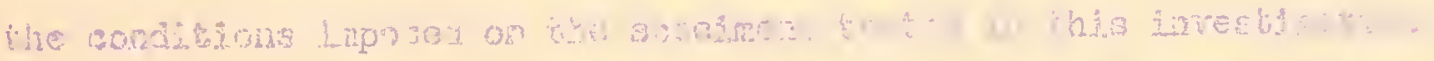

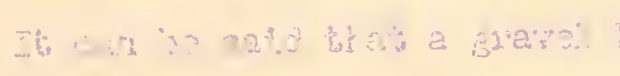

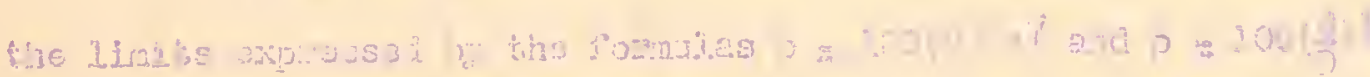

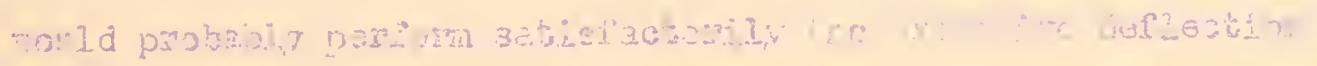

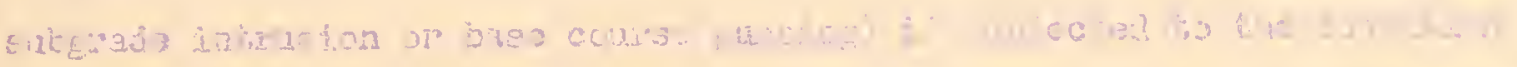

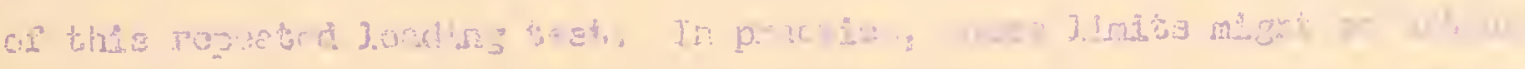

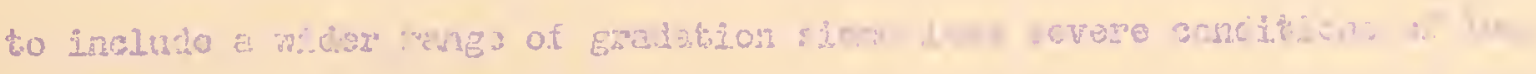

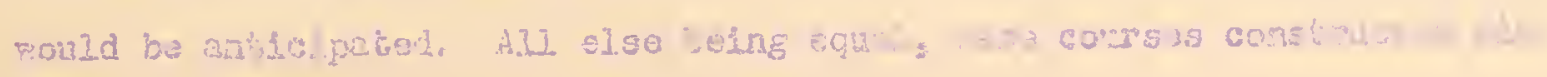




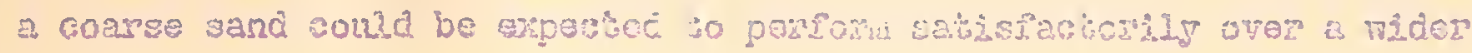

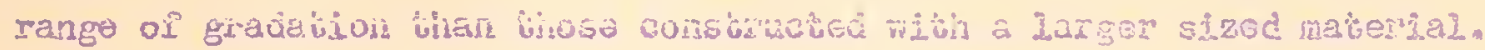




\section{CUNGLLUSIUAS}

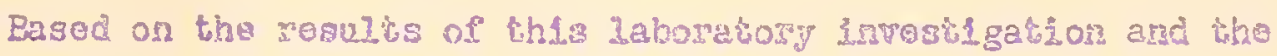

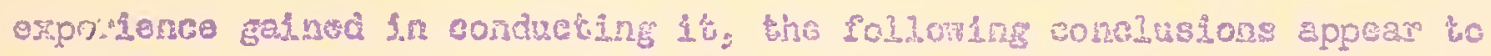
bs justiff1sd:

1. Unoer the propar conditlong of notsture and londy a densmo graded base cousso matertal ipitin an appreciablo percentage of materia. flnor sthan the Ho. 200 mash gateve could bo expegted to have sone of 1 th

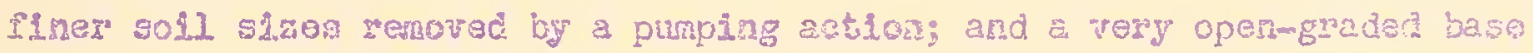
course matertal could be arposted to be conteninatsd by the intrugton of

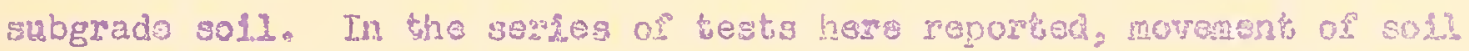

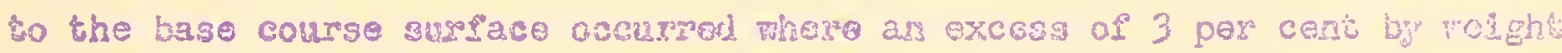

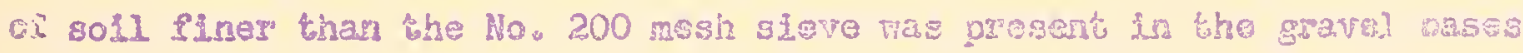

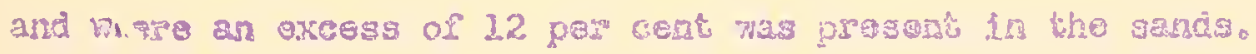

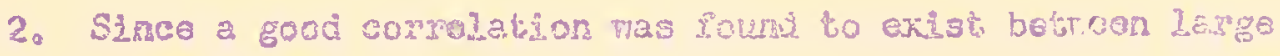

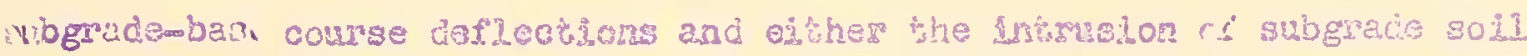

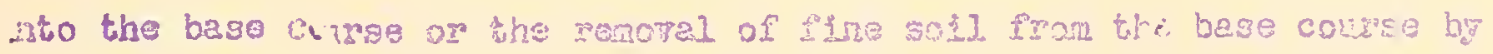
purping actor, 1 is consluded that as apprectabio degroo of arkgrade

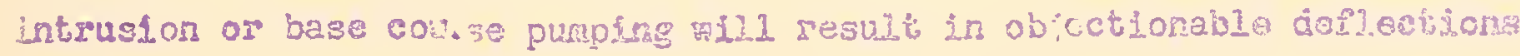
of the subgradembase corge syster.

․ The pinolpl: arfect of a dacrear 3 in the dograe of base

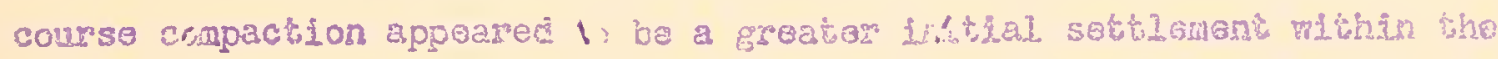

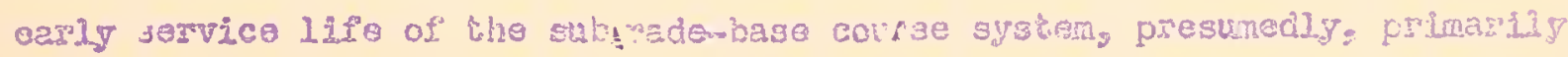
Witidn tha base course.

4. An optinun renge of gredea 0 appears to origh within which 


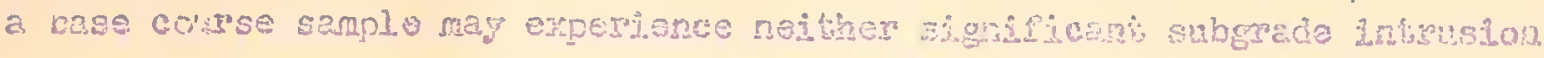

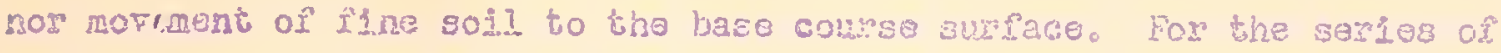

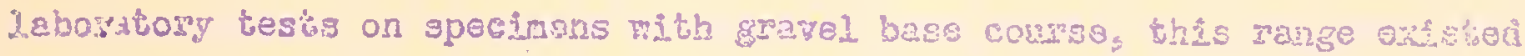

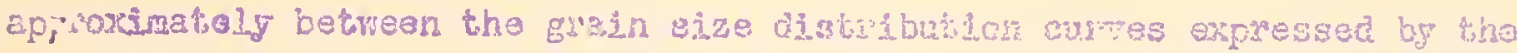

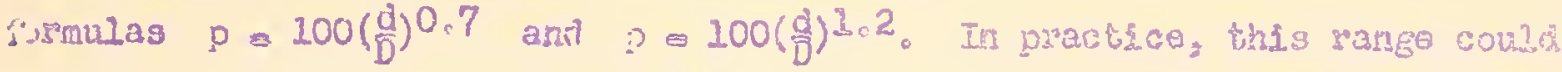

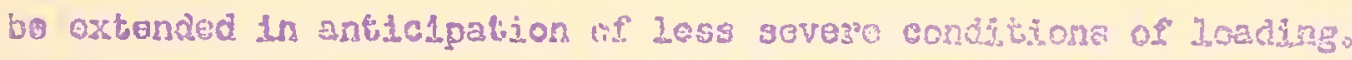

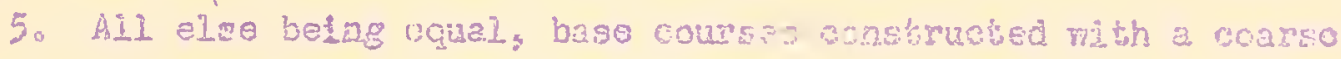

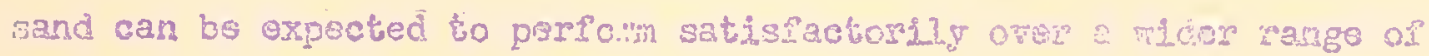

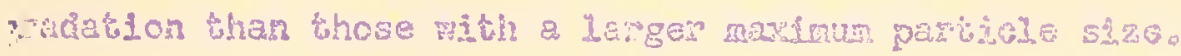

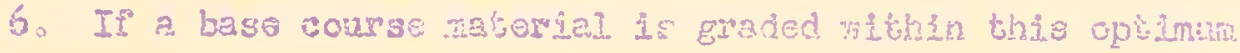

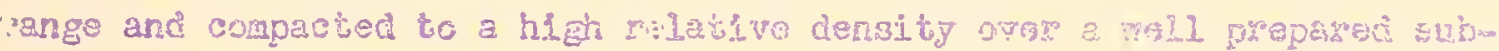

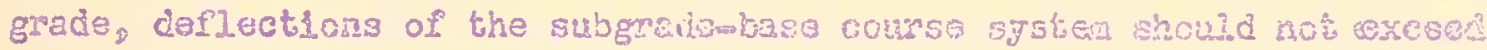

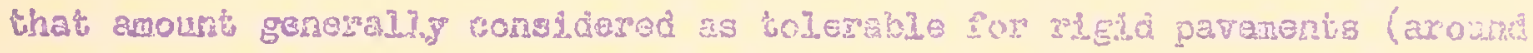
0.05 snch)。

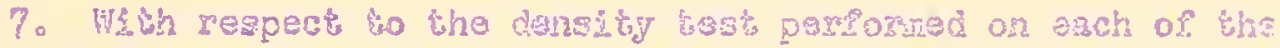

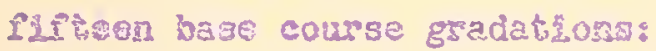

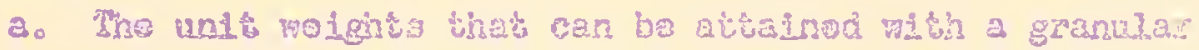

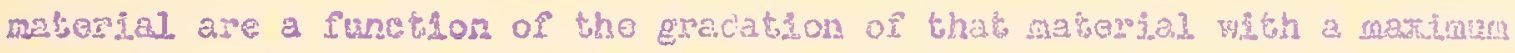
talue attainable when the aggregato 16 graded to sono approximation of

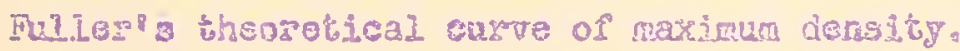

b. Thara is a certaln range of gradacton about ful? curve where smali, chargos in tho grasn siga distributicn of an aggregaive marlsady orfect thr unt naights that car bo steridged.

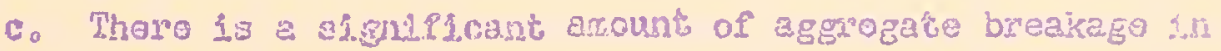

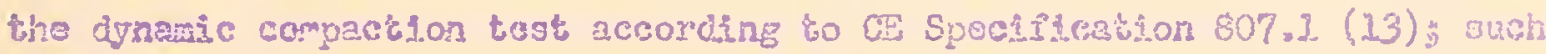
that. In some caseo unit wolghts nay bo incicated for a givon matorial that

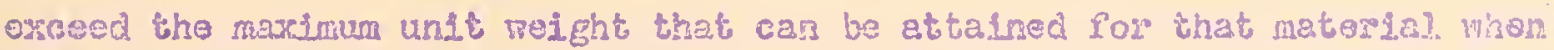


Its gradation 1s not altered by byealrage.

8. It appears that tha filts critoria adoptod by the Corpg of Engineers, U. S. Amy (10) for the protection of thin base courses against the intruston of subgrade soil. are adequate and, in fact, aro somewhat conservative, insofa: as intrusion resulting from a kneading action is concerned.

9. The results of this investigation indicate that nure cono slderation should justifichly ba given to sand as a more satisfactory base course gazteriaj. than graval. 


\section{BIBLIOGRAPHY}

1. Allen, C. Wo and ChILds, L. Do, "Report on Parement Research Project in Onto," Highway Research Board, Bujletin 116, 1956.

2. American Association of State Highway Officials, Standard Specifjcations for Highway Hatorlals and Ulthods of Samol Ing and Tosking, Part II Viashington, 1955.

3. Belcher, D。 J.g Gregg, Lo E. and ï̈oods, Ko B, "The Formation, Distribution and Enginearing Cheractoristics of Solls " Highwar Research Eulieijn No, 20, Purdue University, Laỉagette, Indiana, January, 1943.

40 Bertran, $G_{0} E_{n}$, "An Experinental Investigation of Protective Filtors," Soll blechanica Sorles No. 7g Graduato school of Jingineering, Harvard Undversjty, January, 1.940.

5. Buchanan, $S_{0} I_{0}$ and Khuris $F_{0} I_{0}$ NElastic and Flastle Properties of Solis and their Influence on the Continuous Support of Rigld Pavements " Research Report prepared for the Corps of Ingineers, Ua Sa Army, June, 1954。

6. Bumister, D。 ha, "The Grading-Density Rejations of Granuiar Matorials," Procesdings. Anerican Soclety for Tenting Watorials, Vol. 381938.

7. Burmister, Do Hog "Ths Importance and Practical Use of Relative Density in Soll Hemhanics," Procoodings, Amorican Soc1ety for Iesting Materiels, Vol。 48, 1949.

8. Eumiator, D. Hog "A Srudy of the Physical Characteristics of Solls ith Speclai Reference to Earth Structureg," Buldetin No, 6 Civil Enginearing Rsaearch Laboratorios, Columbia Univorsity, June, 1938 .

9. Corps of Engineers, U. S. Amy, "Airfield Favament Design, Rigid

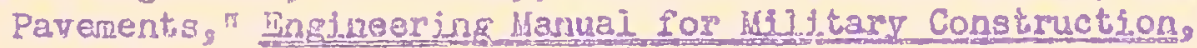
Part XII, Chepter 3, May, 1956。

10. Worps of Enginoers, U. So Aray, "Ajxiseld Pavenent Design, Frost Conditions " Enginsering Manial for Lilitasy Constructiong Part XII, Cheptier 43 Uctober, 1954.

11. Corps of Engineers, U, S, Axny, "Dralnage and Erosion Control-Subsurface

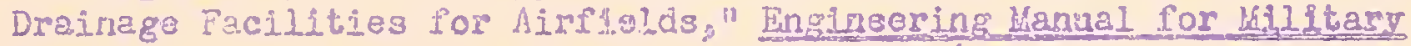
Construction, Part IIII, Chapter 2 , July, 1.946.

12. Cosps of Engineers: U. So Amy, "Investigation of Filtor Requirements for Underdrains," Technical Nemorandum No. 183-i, U. S. Watervags Experiment Station, Vicksburg, Hississippl, November, 1941.

33. Jorps of Englneers, U. S. Ammy. Pavement Flexible, Select Materlal Base Course. Sp9o, CF 807,1, March, 1946, revised, 195:。 
14. Corps of Engineers, U。 S. Arroy, "Righd Pavenent Pumplng Experlence Frost Investigations, 1953," Arctic Construction and Frost Effects Laboraiory, New England Division, 1954。

15. Corps of Engineers, U. S. Army, "The Unified Soll Classtelcation System," Technicia? Memorandum No 3-352, Waterways Experiment station, Yicksburgy H1s818sappi, Marci, 1953.

16. Tuller, 1f. Bo and Thompson, S. Fog "Ihe Laws of Proportioning Conerete," Transactiong, Ararican Society of Civil Engineers, Volo IIX, 1907.

17. Havers, Jo A。 ano Yodor, E. J, "A Stuiy of the Interactions of Selected Combinations of Subgrade and Base iourse Subjected to Repeased Loading" " A papex, presented at the Thirty-Sixth Annus 1 Meeting of the Hignway Hosearch Board, Washigiton, $D_{0} C_{0}$, January, 1957.

18. Hender'son, E. A, and Spencer", "ro, "Effeci of Experinental Subgrado Troatments on Pavoment Faurting and Puning," Procoedings, Highway Reseren Bond, Vol. 26, 1946.

19. Hzghmay Research Buard, "Final Report ort Rocd Test Ono on Mdo," Speclal Raport 4 . Naticnal Acaceny of Sciencu Nationel Research Counc:1, Publication 22\%, 1952.

20. Inaiana, State Highway Cownision, Standaxd Scocipjesions for Road and Brydge Consiruction and Maintonerice, 1952.

21. Indlana, State HIghwy Comatsoion, Vartous urpublished records of constructlon.

22. Karpoff, Ko F. "The Use of Laboratory Testo to Develop DesLgn "interia for Protoctivo Filtorg" Proceedings, Anerican Socloty for Testing Matorlals, Bol. 55, 1955 .

23. Keene, Phil1p, "Underdrain Practice of tho Connecticut Highray Deparkanig" Propeadings, Highway Resoarch Board, Bol. 24, 1944.

24. Lambe, T. Wog Soli Testing for Engineers, John Wiley \& Sons, Inc., Now York, 1951.

25. Lane, Konseth $S_{\circ}$ "Providenco Vibrated Density Test," Proceodings, Second International Conference on Soll Bechanico and Foundation Engineering, Vol. IV, 1948 .

26. Leonards, G. A., "Strength Characteristice of Compacted Clays," Transactiong, American Society of Civil Engineers, Vol. 121, 1955.

27. Melaughlin, Jo Fo, "The Loadocarrying Characteristics of a Biturinous Concrete Resurfacing Mixture," A Thosis subnittod to the faculty of Purdue Univorsity in Partial Fulfillment of the Requirenents for the Degree of Doctor of Philosophy, Purdue University, January. 1957.

28. Shelburno, T。 E。 "Crushing Resistance of Surface-Treatment Aggregation," Research Series No. 76, H1ghwar Rosaarch Bulletin No. 5, Purdue Univorsity, Lafayette, Indlana, Soptember, 1940 . 


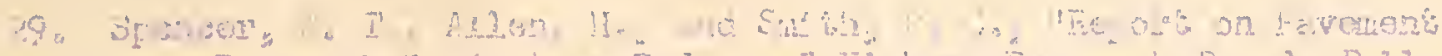

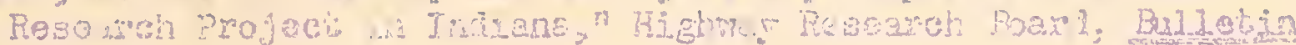
$116,1955$.

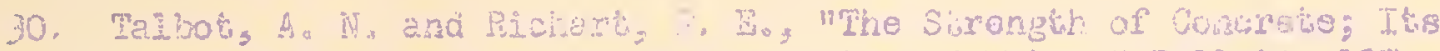

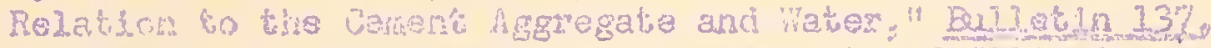

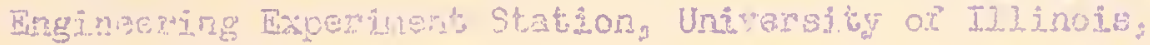
Octotiser $15,1923$.

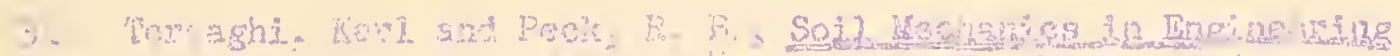

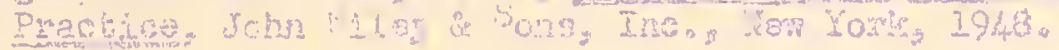

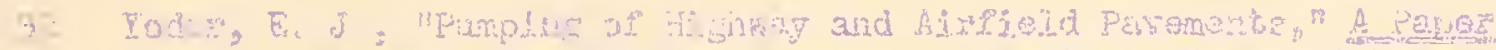

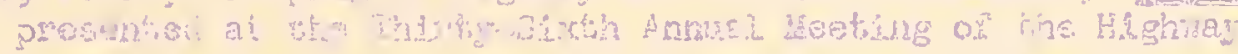

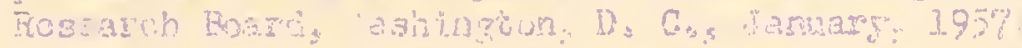



